\title{
Understanding the PEDOT:PSS, PTAA and P3CT-X Hole-Transport-Layer-Based Inverted Perovskite Solar Cells
}

\author{
Qi Bin Ke ${ }^{1}$, Jia-Ren Wu ${ }^{1}$, Chia-Chen Lin $^{1}$ and Sheng Hsiung Chang ${ }^{1,2, *(D)}$ \\ 1 Department of Physics, Chung Yuan Christian University, Taoyuan 320314, Taiwan; \\ qibin050751@gmail.com (Q.B.K.); jrwu@cycu.org.tw (J.-R.W.); s10712114@cycu.org.tw (C.-C.L.) \\ 2 R\&D Center for Membrane Technology and Center for Nano Technology, Chung Yuan Christian University, \\ Taoyuan 320314, Taiwan \\ * Correspondence: shchang@cycu.edu.tw
}

check for updates

Citation: Ke, Q.B.; Wu, J.-R.; Lin, C.-C.; Chang, S.H. Understanding the PEDOT:PSS, PTAA and P3CT-X

Hole-Transport-Layer-Based Inverted Perovskite Solar Cells. Polymers 2022, 14, 823. https://doi.org/10.3390/ polym 14040823

Academic Editor: Jung Kyu Kim

Received: 27 January 2022

Accepted: 17 February 2022

Published: 21 February 2022

Publisher's Note: MDPI stays neutral with regard to jurisdictional claims in published maps and institutional affiliations.

Copyright: (C) 2022 by the authors. Licensee MDPI, Basel, Switzerland. This article is an open access article distributed under the terms and conditions of the Creative Commons Attribution (CC BY) license (https:// creativecommons.org/licenses/by/ $4.0 /)$.

\begin{abstract}
The power conversion efficiencies (PCEs) of metal-oxide-based regular perovskite solar cells have been higher than $25 \%$ for more than 2 years. Up to now, the PCEs of polymer-based inverted perovskite solar cells are widely lower than 23\%. PEDOT:PSS thin films, modified PTAA thin films and P3CT thin films are widely used as the hole transport layer or hole modification layer of the highlyefficient inverted perovskite solar cells. Compared with regular perovskite solar cells, polymer-based inverted perovskite solar cells can be fabricated under relatively low temperatures. However, the intrinsic characteristics of carrier transportation in the two types of solar cells are different, which limits the photovoltaic performance of inverted perovskite solar cells. Thanks to the low activation energies for the formation of high-quality perovskite crystalline thin films, it is possible to manipulate the optoelectronic properties by controlling the crystal orientation with the different polymer-modified ITO/glass substrates. To achieve the higher PCE, the effects of polymer-modified ITO/glass substrates on the optoelectronic properties and the formation of perovskite crystalline thin films have to be completely understood simultaneously.
\end{abstract}

Keywords: p-type polymers; inverted perovskite solar cells; nucleation; crystal growth; perovskite thin film; interfacial contacts

\section{Introduction}

Conductive polymers are widely used in organic photovoltaics (OPVs) and dyesensitized solar cells (DSSCs) as the hole transport layer (HTL) due to their high transparency, large work function and high carrier mobility [1-6]. Poly(3,4-ethylenedioxythiophene) polystyrene sulfonate (PEDOT:PSS) and polyaniline thin films are the most commonly used p-type polymer in organic-related solar cells [7-10]. Ten years ago, the power conversion efficiencies (PCEs) of OPVs and DSSCs were lower than $10 \%$ mainly due to large potential loss $[11,12]$ and strong exciton binding energy $[13,14]$ of the active layer. Fortunately, the organic light-absorbing materials can be replaced by the high-quality perovskite crystalline thin films which can be fabricated by using various solution process techniques under low temperatures ranging from $60{ }^{\circ} \mathrm{C}$ to $140{ }^{\circ} \mathrm{C}$ [15-19], which have largely boosted the PCE of organic-based solar cells to be higher than $20 \%$ in the recent decade. The PEDOT:PSS thin film was used in the first inverted perovskite solar cells, which resulted in a moderate PCE of 3.9\% [20]. The PEDOT:PSS thin films are deposited on top of the ITO/glass substrates as the HTL and electron-blocking layer (EBL), which can influence the open-circuit voltage $\left(\mathrm{V}_{\mathrm{OC}}\right)$, short-circuit current density $\left(\mathrm{J}_{\mathrm{SC}}\right)$ and fill factor $(\mathrm{FF})$ of the resultant perovskite solar cells by varying the molecular structure of the PEDOT chains and the thickness of the PEDOT:PSS thin films [21-24]. However, the PCE values of PEDOT:PSS-based inverted perovskite solar cells are lower than $20 \%$, mainly due to the relatively low $\mathrm{V}_{\mathrm{OC}}$ and FF [25-30], which are originated from the potential loss at the perovskite/PEDOT:PSS interface. Poly(triarylamine) (PTAA)- and poly[3-(4-carboxybutyl) thiophene-2,5-diyl] 
(P3CT)-based thin films have been widely used to replace the PEDOT:PSS thin films, which can increase the $\mathrm{V}_{\mathrm{OC}}$ and FF of the resultant perovskite solar cells simultaneously [31-34]. It can be explained as being due to the reductions of potential loss and carrier recombination in the perovskite layer and at the perovskite/HTL interface [35-38]. The surface wettabilities of the PEDOT:PSS, P3CT-X (X: Na, K, Rb, Cs) and PTAA thin films are superhydrophilic, hydrophilic and hydrophobic, respectively, which can largely influence the film discontinuity and grain size of the deposited perovskite thin films $[39,40]$.

Hydrophobic $\mathrm{NiO}_{\mathrm{x}}$ - and $\mathrm{CuO}_{\mathrm{x}}$-based thin films are also widely used in the inverted perovskite solar cells as the HTL [41,42]. The photovoltaic performance of $\mathrm{NiO}_{\mathrm{x}}$-based inverted perovskite solar cells can be increased to be higher than $20 \%$ by using an organic interlayer in between the perovskite thin film and the HTL [43-47]. In other words, the formation of high-quality perovskite crystalline thin films is not only related to the surface wettability [48-50] but is also dominated by the nucleation process of perovskites on top of the organic layers. Conceptually, the formation of uniform nucleation sites can form preferred oriented perovskite crystalline thin films, which is similar to the crystal growth of perovskites on top of the single-crystalline wafer [51] or organic self-assemble (SAM) monolayer modified substrates [52,53].

On the other hand, the surface properties of HTL dominate the grain size, surface roughness and crystal orientation of the resultant perovskite thin films and thereby influence the contact quality at the electron transport layer (ETL)/perovskite interface. In the inverted perovskite solar cells, $\mathrm{C}_{60}$ and (phenyl- $\mathrm{C}_{61}$-butyric acid methyl ester) PCBM thin films are widely used as the ETL [54-57]. It is noted that the surface roughness of perovskite crystalline thin films determines the formation of the s-shaped $\mathrm{J}-\mathrm{V}$ curves in the PCBM/MAPbI 3 heterojunction solar cells [58-60]. Besides, the solutionprocessed bathocuproine $(\mathrm{BCP})$ and thermal evaporated $\mathrm{BCP}$ can be used to modify the $\mathrm{C}_{60}$-derivatives-based ETL, which largely increases the FF of the resultant perovskite solar cells [61-64]. BCP molecules and oxygen-containing functional group of PCBM molecules can passivate the electron-poor defects at the grain boundaries of perovskite thin films due to the sub-nanometer scale. $\mathrm{C}_{60}$ molecules can passivate the electron-rich defects at the grain boundaries of perovskite thin films due to the electron chargeable property. However, the $\mathrm{V}_{\mathrm{OC}}$ hysteresis can still be observed in the J-V curves, which indicates that the surface defects of perovskite crystalline thin films are not completely passivated by the capping layer. In other words, the crystal orientation of perovskite thin films plays an important role, which determines the types of surface defects in the top region.

According to the theoretical calculations, the highest PCE of the inverted perovskite solar cells is about $30 \%[65,66]$, which is lower than the highest prediction value from Shockley-Queisser (S.-Q.) limit because the absorption bandgap of lead trihalide-based perovskite material is higher than the optimal absorption bandgap [67,68]. Up to now, the highest PCE values of regular perovskite solar cells and inverted perovskite solar cells are $25.59 \%$ [69] and $23.32 \%$ [70], respectively. In the best regular perovskite solar cell, a mesoporous- $\mathrm{TiO}_{2} /$ compact- $\mathrm{TiO}_{2}$ bilayer structure is used as the ETL. In the best inverted perovskite solar cell, a phenylethylammonium iodide (PEAI)-modified PTAA thin film is used as the HTL while improving the contact quality at the ETL/perovskite interface via the treatment of PEAI molecules. Compared with the photovoltaic performance of the most regular perovskite solar cells, the $\mathrm{V}_{\mathrm{OC}}$ and FF of the most inverted perovskite solar cells are relatively lower mainly due to the larger potential loss and higher carrier recombination. In other words, there is still room for improvement in the PCE of inverted perovskite solar cells.

In this review, we focus on the understanding of highly efficient inverted perovskite solar cells. In the following sections, the working mechanism of perovskite solar cells will be mentioned first. The research progress of the polymer-based inverted perovskite solar cells will be mentioned in order to discuss the possible future directions, which is divided into three sections: PEDOT:PSS-based perovskite solar cells, PTAA-based perovskite-based 
solar cells and P3CT-X-based solar cells. Finally, the ways to realize $25 \%$ inverted perovskite solar cells are discussed.

\section{Working Mechanisms of Perovskite Solar Cells}

Figure 1 presents the device architectures of a regular-type perovskite solar cell and an inverted-type perovskite solar cell. In the regular perovskite solar cell, the n-type metal oxides are widely deposited on top of the FTO/glass substrates with a post-sintering treatment. The metal oxide layer can be $\mathrm{TiO}_{2}, \mathrm{SnO}_{2}, \mathrm{ZnO}$ and $\mathrm{Al}$-doped $\mathrm{ZnO}$, which collects the photogenerated electrons and blocks the photogenerated holes simultaneously. In the inverted perovskite solar cell, the p-type polymers and p-type metal oxides are widely fabricated on top of the ITO/glass substrates with a post-thermal annealing process at about $100{ }^{\circ} \mathrm{C}$. The high-quality perovskite crystalline thin films can be fabricated by using the two-step spin coating method with an interdiffusion process [71-73], the one-step spin coating method with a washing-enhanced nucleation (WEN) process [74-76] and the vacuum thermal co-evaporation technique [77-79]. The organometal trihalide perovskite can be $\mathrm{CH}_{3} \mathrm{NH}_{3} \mathrm{PbI}_{3}\left(\mathrm{MAPbI}_{3}\right), \mathrm{CH}\left(\mathrm{NH}_{2}\right)_{2} \mathrm{PbI}_{3}\left(\mathrm{FAPbI}_{3}\right)$ and $\mathrm{Cs}_{\mathrm{x}}\left(\mathrm{MA}_{\mathrm{y}} \mathrm{FA}_{1-\mathrm{y}}\right)_{1-\mathrm{x}} \mathrm{Pb}\left(\mathrm{I}_{\mathrm{z}} \mathrm{Br}_{1-\mathrm{z}}\right)_{3}$, mainly due to the low absorption bandgap [80-82], large absorption coefficient [83-85], small exciton binding energy [86-88], long exciton (carrier) lifetime [89-91] and high carrier mobility [92-94]. The capping layers for the regular perovskite solar cell and inverted perovskite solar cell are p-type small molecules [95-97] and n-type small molecules [98-100], respectively. In other words, the p-type capping layer (n-type capping layer) has to collect the photogenerated holes (electrons) and passivate the electron-rich defects (electron-poor defects) in the top region of the perovskite crystalline thin films, as shown in Figure 2. In the regular perovskite solar cell, the use of a hole modification layer can increase the hole collection efficiency and block the photogenerated electrons from the perovskite layer [101-103]. In the inverted perovskite solar cells, the film quality of the ETL and the contact quality at the ETL/perovskite interface can be improved via a BCP/IPA solution treatment process, which can improve $\mathrm{V}_{\mathrm{OC}}, \mathrm{J}_{\mathrm{SC}}$ and FF simultaneously [104-106]. Au (Cu) and Ag (Al) metals are used as the anode electrode and cathode electrode, respectively.
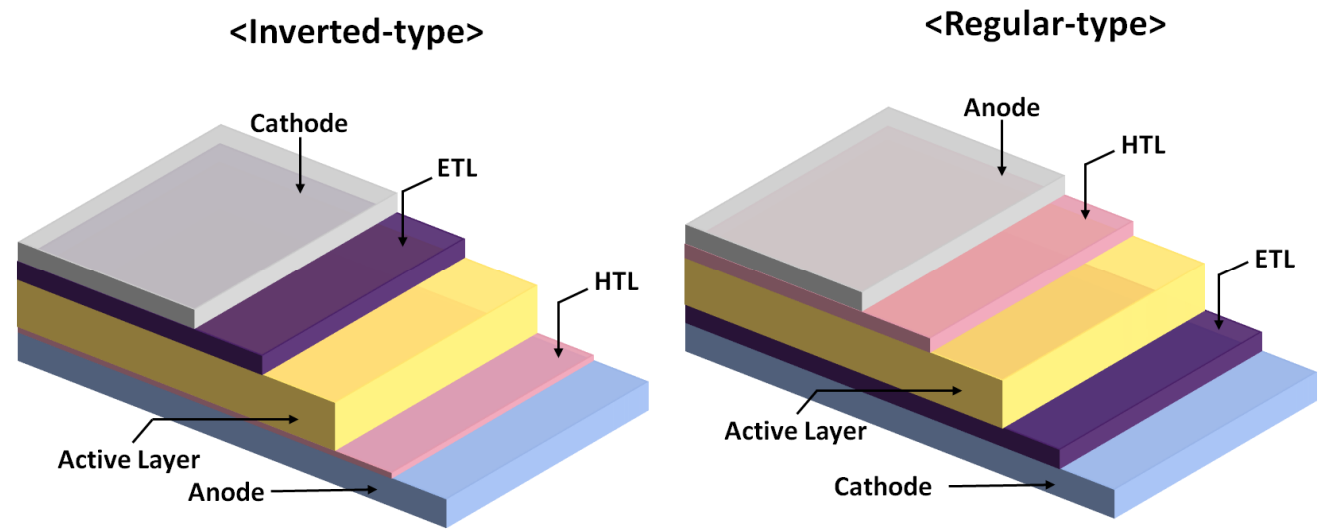

Figure 1. Device architectures of an inverted perovskite solar cell and a regular perovskite solar cell. ETL and HTL denote electron transport layer and hole transport layer, respectively.

The highest FF values of regular perovskite solar cells and inverted perovskite solar cells are 85\% [107] and 86\% [108], respectively. The high FF values can be mainly explained as due to the existence of organic dipoles in the organometal trihalide perovskites, which has been demonstrated theoretically and experimentally $[109,110]$. The photoinduced organic dipolar alignment suggests that the electron flow and hole flow are spatially separated in the perovskite crystal and thereby eliminate the defect-mediated carrier recombination after the exciton self-dissociation. It is noted that the photogenerated hole transportation is better than the photogenerated electron transportation in the bifacial inverted perovskite solar cells, which results in the higher FF under a sunlight illumination from the semitransparent 
cathode electrode [111]. In other words, the hole mobility in the regular perovskite solar cell is higher than the electron mobility in the inverted perovskite solar cell, as shown in Figure 3. Fortunately, the carrier mobility of perovskites is related to the crystal orientation [112-114]. Therefore, it is possible to improve the photovoltaic performance of inverted perovskite solar cells via tuning the polycrystalline thin film to the most appropriate orientation plane in order to facilitate the collections of photogenerated carriers without the potential loss and carrier recombination. Conceptually, the molecular packing structure of the p-type polymers determines the preferred crystal orientation of the perovskite crystalline thin films, thereby dominating the photovoltaic performance of the resultant perovskite solar cells. In other words, the molecular structure and molecular packing structure of the HTL on top of the ITO/glass (FTO/glass) substrate can be used to understand the photovoltaic performance of the PEDOT:PSS-, PTAA- and P3CT-X-based inverted perovskite solar cells. The photovoltaic performance of the best PEDOT:PSS-, modified PTAA- and P3CT-X-based inverted perovskite solar cells is listed in Table 1.

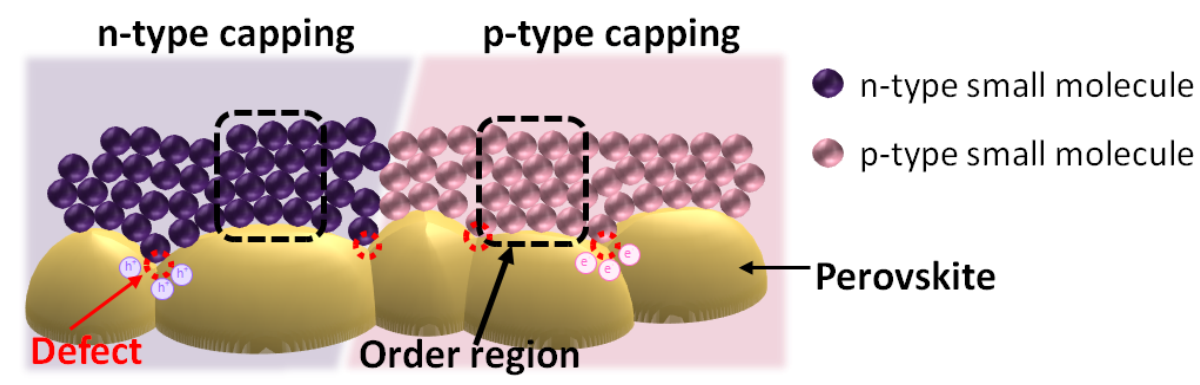

Figure 2. ETL/perovskite and HTL/perovskite interfaces.

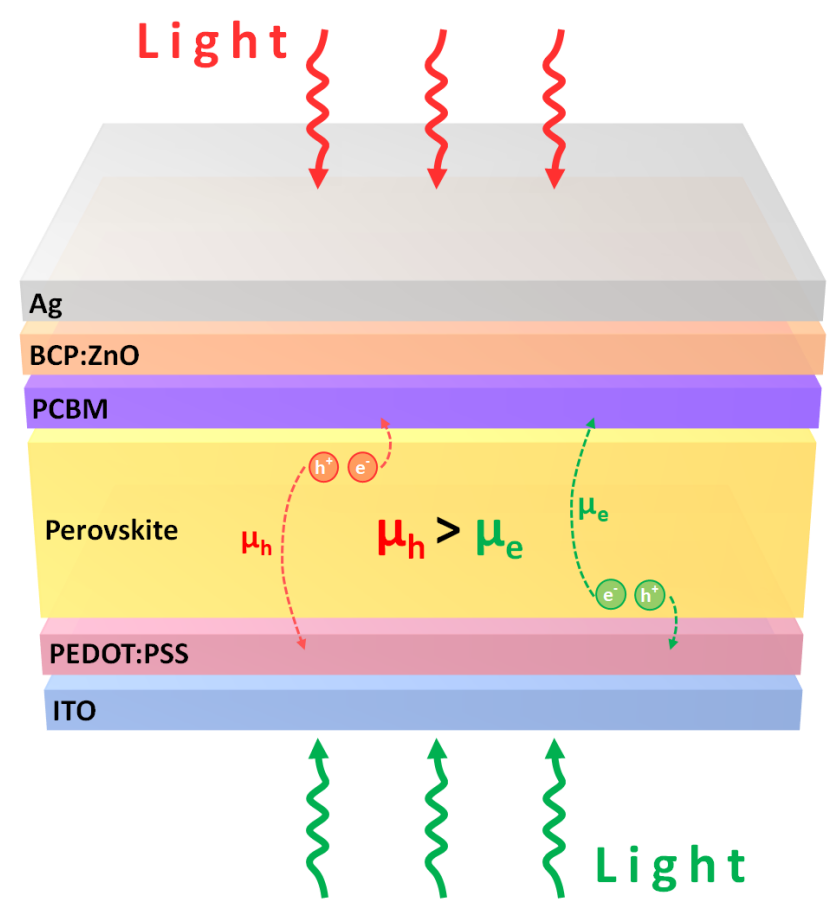

Figure 3. Electron and hole transportations of a bifacial perovskite solar cell. 
Table 1. Photovoltaic performance of the best PEDOT:PSS-, modified PTAA- and P3CT-X-based inverted perovskite solar cells under one sun illumination (AM 1.5 G, $100 \mathrm{~W} / \mathrm{cm}^{2}$ ).

\begin{tabular}{|c|c|c|c|c|c|c|c|}
\hline P-Type Polymer & Perovskite & $\begin{array}{l}\text { Grain Size and } \\
\text { Thickness of } \\
\text { Perovskite (nm) }\end{array}$ & $\mathrm{V}_{\mathrm{OC}}(\mathrm{V})$ & $\begin{array}{c}\mathrm{JSC}_{\mathrm{SC}} \\
\left(\mathrm{mA} / \mathrm{cm}^{2}\right)\end{array}$ & FF (\%) & PCE (\%) & Ref. \\
\hline PEDOT:PSS & $\mathrm{MAPbI}_{3}$ & $1500 / 470$ & 1.060 & 23.10 & 86.0 & 21.05 & [108] \\
\hline Modified PTAA & $(\mathrm{MAFA}) \mathrm{Pb}(\mathrm{ICl})_{3}$ & $350 / 550$ & 1.155 & 24.13 & 83.7 & 23.32 & [70] \\
\hline Р3СТ-X & $(\mathrm{CsMAFA}) \mathrm{Pb}(\mathrm{IBr})_{3}$ & $300 / 400$ & 1.120 & 22.78 & 83.6 & 21.33 & [115] \\
\hline
\end{tabular}

\section{PEDOT:PSS Thin-Film-Based Perovskite Solar Cells}

In the first inverted perovskite solar cell, a PEDOT:PSS thin film is used as the HTL, which results in a moderate PCE of 3.9\%. The PEDOT:PSS (1:6 wt \%) thin films were widely used in the poly(3-hexylthiophene): [6,6]-phenyl $\mathrm{C}_{61}$-butyric acid methylester (P3HT:PCBM) blended thin-film-based OPVs as the HTL mainly due to the efficient holecollection and electron-blocking abilities. Figure 4 a presents the molecular structures of PEDOT and PSS polymers. The PEDOT and PSS are p-type polymer and large-bandgap polymer (insulator), respectively. The long-chain PEDOT polymers can be doped by shotchain PSS polymers, thereby forming the linear molecular structure, which increases the doping concentration and work function of the PEDOT chains in the PEDOT:PSS thin films [116-118]. In the non-modified PEDOT:PSS thin-film-based perovskite solar cells, the highest PCE is lower than $17 \%$ mainly due to the relatively low $\mathrm{V}_{\mathrm{OC}}$ and FF. The PEDOT:PSS thin films are amorphous and hydrophilic surfaces, which results in the high nucleation density during the formation of perovskite crystalline thin films, as shown in Figure $4 \mathrm{~b}$. In other words, the grain sizes of perovskite crystalline thin films deposited on top of the PEDOT:PSS/ITO/glass samples are smaller than $500 \mathrm{~nm}$, which results in the sub-micrometer-sized perovskite grains, thereby forming the carrier recombination centers in the grains to reduce the $\mathrm{V}_{\mathrm{OC}}$ and FF of the resultant solar cells. The PCE of the PEDOT:PSS thin-film-based perovskite solar cells can be increased from $15 \%$ to $18 \%$ via adding p-type graphene oxide (GO) into the HTL [119]. Conceptually, the carbon-based hydrophobic additives into the HTL can increase the grain size of perovskite crystalline thin films, which can increase the $\mathrm{V}_{\mathrm{OC}}, \mathrm{J}_{\mathrm{SC}}$ and FF simultaneously [120-122]. However, there is a trade-off between the grain size and surface roughness in the perovskite crystalline thin film because the thickness of the solution-processed $\mathrm{C}_{60}$-derivatives-based ETLs is about $50 \mathrm{~nm}$. The smaller grain size results in the higher defect density in the perovskite crystalline thin film, thereby reducing the $\mathrm{V}_{\mathrm{OC}}$ and FF. The larger grain size results in the roughed perovskite crystalline thin film, which cannot be completely covered by a $50 \mathrm{~nm}$ thick ETL and thereby reduces the $\mathrm{V}_{\mathrm{OC}}$ and FF.

GO contains the hydroxyl $(-\mathrm{OH})$, oxo $(=\mathrm{O})$ and carboxyl $(-\mathrm{COOH})$ groups [123]. The hydroxylgroup can increase the surface wettability of GO thin films, thereby increasing the contact quality at the perovskite/GO-doped PEDOT:PSS interface. The oxo group can passivate the electron-poor defect in the bottom surface of the perovskite crystalline thin films. After the dehydrogenation reaction of the carboxyl group, the ester group can be the nucleation site of the perovskite thin film, thereby increasing the contact quality at the perovskite/p-type GO interface. However, the formation of hydrogen iodide (HI) molecules can result in the iodide vacancies in the bottom region of the resultant perovskite crystalline thin film. On the other hand, the sulfonic acid $\left(-\mathrm{SO}_{3} \mathrm{H}\right)$ groups of the PSS in the PEDOT:PSS thin film can be considered as the nucleation sites at the perovskite/PEDOT:PSS interface after the dehydrogenation reaction. In other words, the dehydrogenation reaction of the PSS polymers can form the iodide vacancies in the perovskite crystalline thin film, which can be used to explain the formation of JSC hysteresis in the J-V curves of the PEDOT:PSS thin-film-based perovskite solar cells [124-126]. On the other hand, the metal oxides $\left(\mathrm{MoO}_{\mathrm{x}}, \mathrm{GeO}_{2}\right.$ and $\left.\mathrm{NiO}_{\mathrm{x}}\right)$ are added into the PEDOT:PSS thin films in order to increase the photovoltaic performance of the PEDOT:PSS thin-film-based perovskite solar 
cells [127-129]. Their experimental results show that the addition of metal oxides into the PEDOT:PSS thin films improves the hole collection efficiency and the contact quality at the perovskite/HTL interface.

(a)
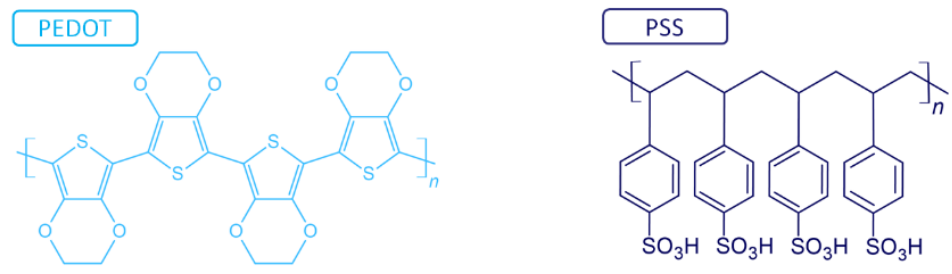

(b)

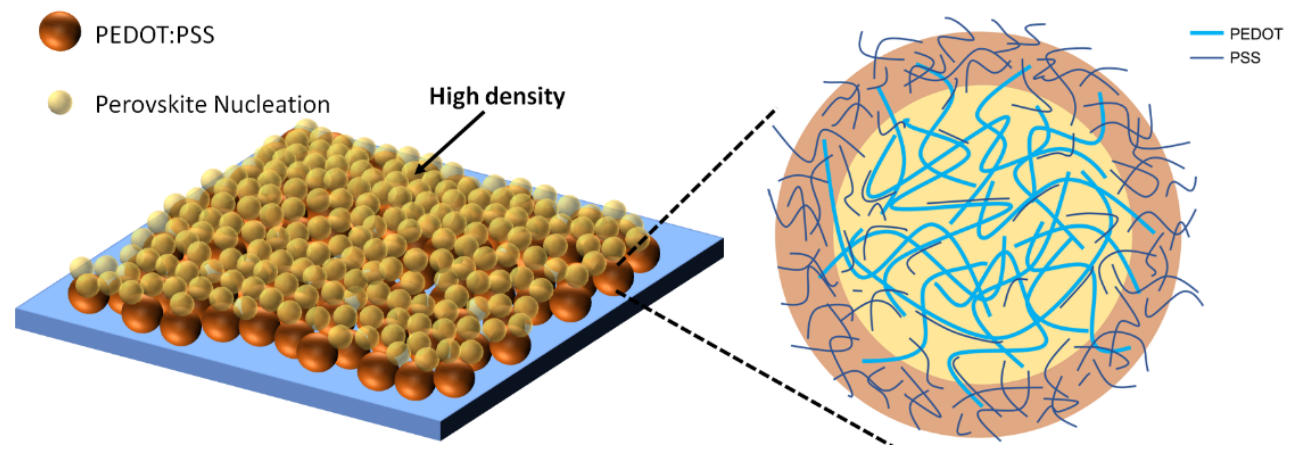

Figure 4. (a) Molecular structures of PEDOT and PSS polymers. (b) High-density perovskite nucleation points on top of the hydrophilic PEDOT:PSS thin film.

\section{PTAA Thin-Film-Based Perovskite Solar Cells}

The p-type PTAA polymer was proposed to replace the Spiro-OMeTAD small molecule in the regular perovskite solar cells as the HTL and capping layer mainly due to higher glass transition and melting temperature $[130,131]$. In the regular perovskite solar cells, the thickness of the p-type capping layer is higher than $100 \mathrm{~nm}$ in order to completely cover the roughed perovskite crystalline thin film. To increase the hole mobility, dopants are widely added into the HTL. However, the dopants in the HTL also resulted in the shorter lifespan of the resultant perovskite solar cells mainly due to the diffusion of dopants into the active layer. Up to now, the highest PCE values of the PTAA-based regular perovskite solar cells and the Spiro-OMeTAD-based regular perovskite solar cells are 22.1\% [132] and $25.6 \%$ [69], respectively. In recent years, the record high PCE values of regular perovskite solar cells were achieved by using the doped Spiro-OMeTAD thin films as the HTL. In other words, the nanometer-sized PTAA polymers cannot effectively passivate the surface defects at atomic scales, which results in the relatively lower $\mathrm{V}_{\mathrm{OC}}$ and FF. Figure 5 a presents the molecular structure and energy diagram of a PTAA polymer.

In the inverted perovskite solar cells, the micrometer-sized grains of the perovskite thin film can be formed on top of the hydrophobic PTAA thin film [133], which can reduce the surface defect density of the resultant perovskite thin film. When a p-doped PTAA thin film is used as the HTL, the PCE of the inverted perovskite solar cells can be increased to $17.5 \%$ [31]. However, the PCE was still lower than $20 \%$, mainly due to the potential loss in the thick PTAA thin film. In recent years, it was found that an ultrathin face-on PTAA can be used to modify the ITO thin film, which results in higher FF and $V_{O C}$ values. To form pinhole-free closelypacked perovskite thin film on top of the hydrophobic PTAA thin film, a two-step solvent treatment process [134] and a p-type $\mathrm{MoO}_{3}$ dopant [135] can be used to increase the surface wettability, thereby increasing the PCE to be higher than $20 \%$. On the other hand, the used $\mathrm{CuCrO}_{2}$ :PTAA inorganic-organic composite thin film increases the photovoltaic performance of the resultant perovskite solar cells mainly due to the improved hole mobility of the HTL [136]. 
(a)<smiles>Cc1ccc(N(c2ccc(C)cc2C)c2c(C)cc(C)cc2C)cc1</smiles>
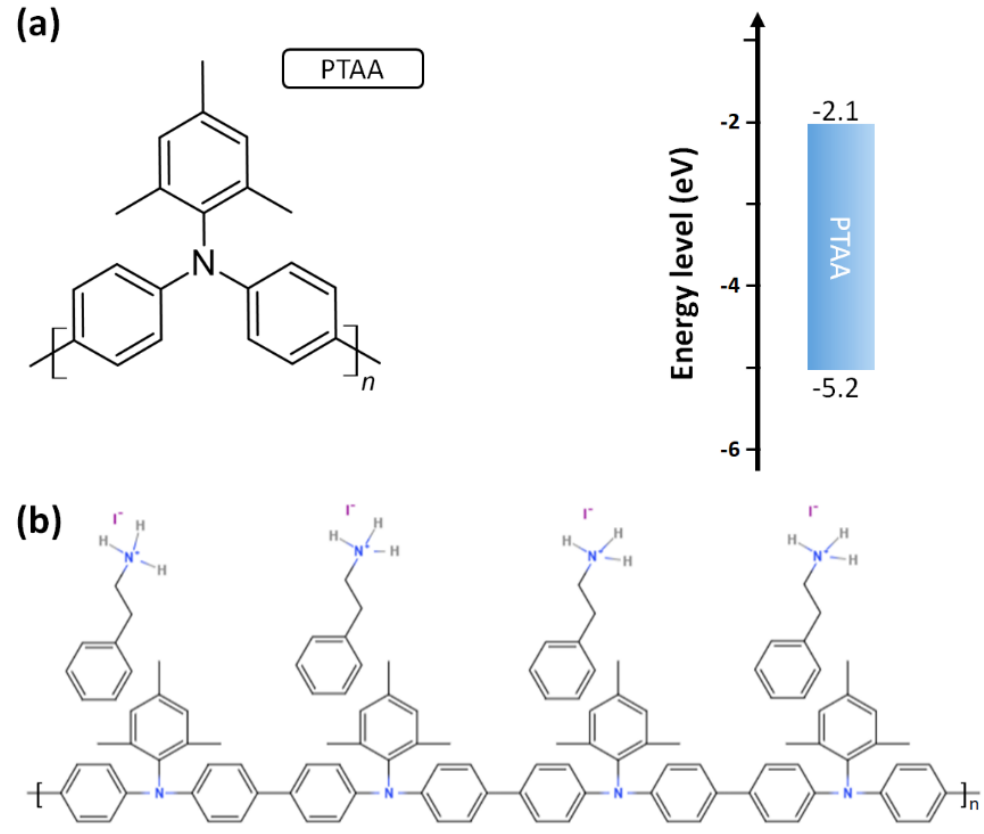

Figure 5. (a) Molecular structure and energy diagram of PTAA. (b) PEAI-modified PTAA.

In the best inverted perovskite solar cell, the PEAI small molecules are used to modify the surfaces of the ultrathin PTAA polymers and perovskite thin film simultaneously [70], as shown in Figure 5b. As an interlayer in between the perovskite crystalline thin film and the face-on PTAA polymers, the phenyl group of the PEAI can lie on the face-on PTAA polymers due to the $\pi-\pi$ stacking, thereby forming the upward ethylammonium iodide group, which can be considered as the nucleation site of the perovskite thin film. As an interlayer in between the PCBM thin film and the perovskite crystalline thin film, the downward ethylammonium iodide group can passivate the iodide vacancy and organic cation vacancy, thereby forming an upward phenyl group, which can facilitate the molecular packing structure of the PCBM thin film via the $\pi-\pi$ contact. In other words, the electron mobilities of the perovskite crystalline thin film and PCBM thin film can be simultaneously increased when the PEAI small molecules are used to modify the surface of the perovskite crystalline thin film, which can be used to explain the high $\mathrm{V}_{\mathrm{OC}}$ and FF.

\section{P3CT-X Thin-Film-Based Perovskite Solar Cells}

The P3CT-Na polymer was proposed to be an alternative material to the HTL in the inverted perovskite solar cells, which resulted in a high PCE of 16.6\% [33]. The P3CT-Na polymer is synthesized by mixing $\mathrm{P} 3 \mathrm{CT}$ and $\mathrm{NaOH}$ in a water solution via the substitution from hydrogen anion to sodium anion. In the first P3CT-Na-based inverted perovskite solar cell, the PCE is limited to be lower than $17 \%$ mainly due to the relatively low FF and $\mathrm{V}_{\mathrm{OC}}$. Figure 6 presents the molecular structure and energy diagram of a P3CT-Na polymer. $\mathrm{P} 3 \mathrm{CT}$ is a hydrophobic polymer, which cannot be effectively dissolved in a water solution at room temperatures. The concentration of the used P3CT-Na/water solution is about $0.15 \mathrm{wt} \%$, which shows that the P3CT-Na polymers can be partially dissolved in water solution due to the hydrophilicity of the Na sites. When the Na cation is replaced by $\mathrm{K}, \mathrm{Rb}, \mathrm{Cs}$ or $\mathrm{CH}_{3} \mathrm{NH}_{3}$ cation, the PCE of the P3CT-X-based inverted perovskite can be increased to be higher than $20 \%[34,137]$. The main concept is that the larger cation size can minimize the formation of sub-micrometer-sized P3CT-X aggregates, thereby forming edge-on P3CT-X polymers on top of the ITO/glass substrate. The molecular structure of P3CT shows that the P3CT-X aggregates have hydrophobic surfaces due to the faceon packing structure. Figure 7 presents the edge-on P3CT-X and face-on P3CT-X on top of the ITO thin film. It is noted that the hydrophobic face-on P3CT-Na aggregates can be effectively removed from the solution by using the double-filtering process, thereby 
forming edge-on P3CT-Na polymers on top of the ITO/glass substrate, which increases the PCE of the resultant inverted perovskite solar cells to be higher than $20 \%$ mainly due to the relatively high JSC $_{S}$ values [35-37]. The higher JSC value might be originated from the better crystallinity of the perovskite crystalline thin film and the better contact quality at the perovskite/P3CT-Na interface, which results in the higher exciton generation and the higher exciton dissociation (hole collection), respectively. On the other hand, the addition of graphdiyne into the P3CT-K thin film increases the photovoltaic performance of the resultant perovskite solar cells mainly due to the better surface wettability of the HTL, which improves the homogenous coverage and reduces grain boundaries of the perovskite thin film [138].
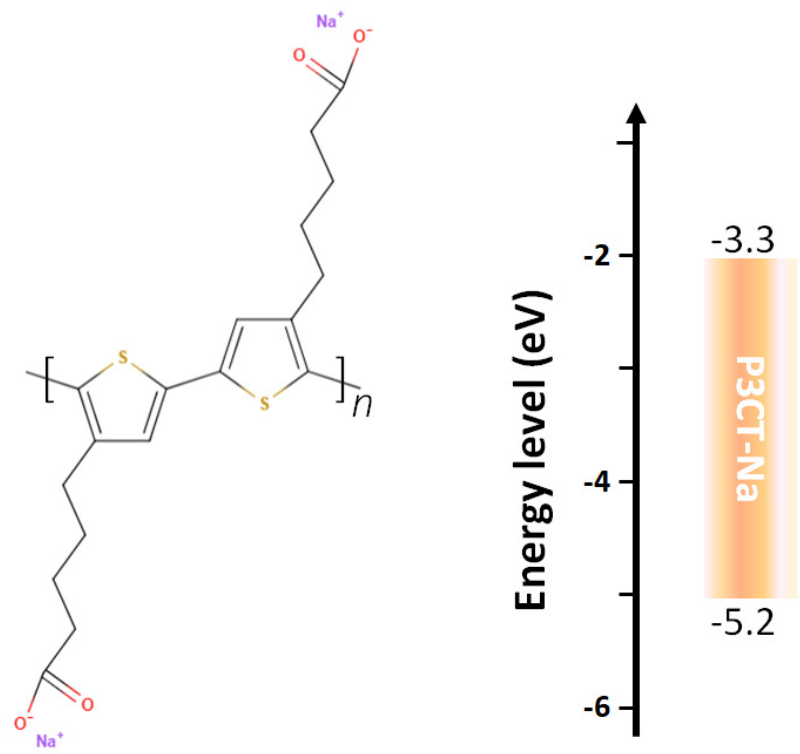

Figure 6. Molecular structure and energy diagram of P3CT-Na.

(a) Edge-on P3CT-Na/ITO

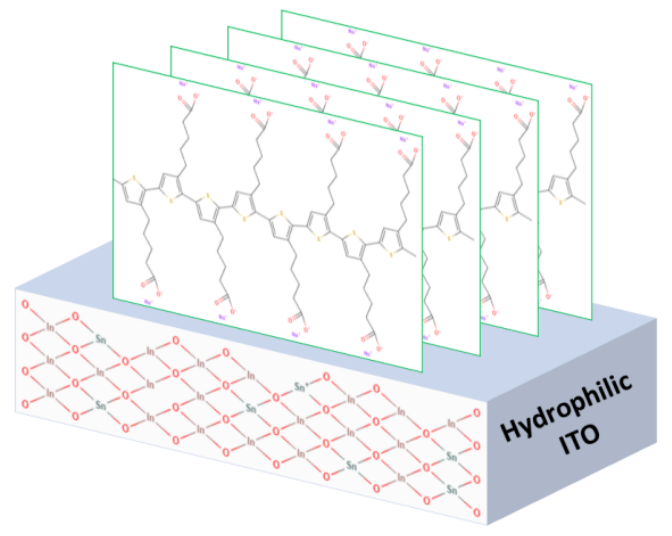

(b) Face-on P3CT-Na/ITO

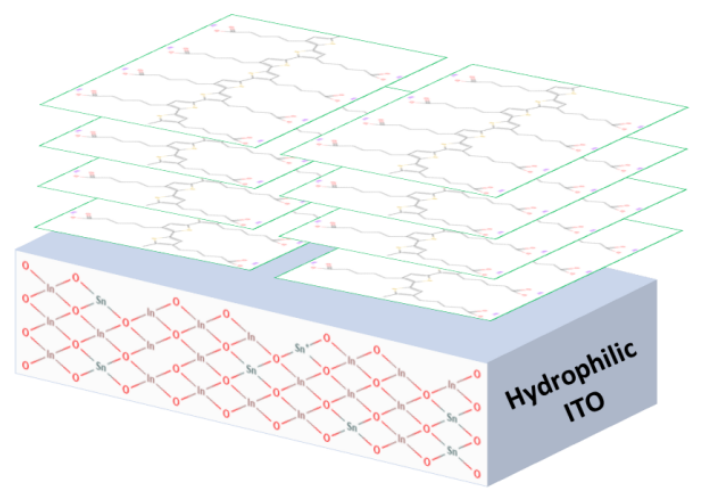

Figure 7. P3CT-Na polymers on top of the hydrophilic ITO thin film. (a) Edge-on. (b) Face-on.

When the P3CT-X polymer is used to replace the PEDOT:PSS polymer, the JSC hysteresis characteristic almost disappears in the J-V curves of the inverted perovskite solar cells. In other words, the use of edge-on P3CT-X polymers can decrease the formation of iodide vacancies in the inner region of the perovskite grains. Conceptually, the hydrophilic cations in the upper side and bottom side of the edge-on P3CT-X polymers can connect with the perovskite crystalline thin film and ITO thin film, respectively. The formation of edge-on P3CT-Na polymers is related to the surface chemical compositions (oxygen defect density) of the ITO thin films [139]. The experimental results show that the formation of 
edge-on P3CT-Na polymers on top of the Sn-rich ITO thin film is better, which results in a hysteresis-free and highly stable inverted perovskite solar cell. The extremely low JSC hysteresis characteristic in the J-V curves shows that the upward Na sites of the edge-on P3CT-Na polymers are used to replace the organic cations as the nucleation sites of the perovskite crystalline thin films, thereby minimizing the formation of iodide vacancies.

\section{Understanding of Highly-Efficient Inverted Perovskite Solar Cells}

The formation of closelypacked perovskite crystalline thin films plays an important role in realizing the highlyefficient perovskite solar cells. The WEN process has been widely used to form the smooth and high-quality perovskite crystalline thin films on top of the various hydrophilic or hydrophobic substrates because the used antisolvents can balance the nucleation and crystal growth rates. However, the nucleation and crystal growth of the perovskite crystalline thin film are also related to the surface properties of the substrates. In 2015, it was found that the grain sizes of the perovskite crystalline thin films can be increased by decreasing the surface wettability of the substrates [140]. Therefore, the PTAA and poly[ $N, N^{\prime}$-bis(4-butylphenyl)- $N, N^{\prime}$-bis(phenyl)-benzi (poly-TPD) thin films are widely used as the HTL of the inverted perovskite solar cells [141-144]. To completely cover the surface of the roughed ITO thin film, the thickness values of the conjugated polymer thin films are larger than $50 \mathrm{~nm}$. Therefore, the additional dopants have to be used in order to increase the hole mobility of the thick conjugated polymer thin films. Besides, the micrometer-sized perovskite grains result in the relatively roughed surface, which can be used to explain why the thicker $\mathrm{C}_{60} / \mathrm{PCBM}$ bilayer or $\mathrm{ZnO} / \mathrm{PCBM}$ bilayer is used as the ETL to cover the perovskite crystalline thin film. The device architecture of a thick HTL-based inverted perovskite solar cell is plotted in Figure 8. In the inverted perovskite solar cells, the photogenerated holes can be collected at the perovskite/HTL interface. Then, the photogenerated electrons must diffuse to the ELT/perovskite interface, which influences the generation efficiency of photocurrents. In other words, the hole mobility of HTL, the electron mobility of perovskite thin film and the electron mobility of ETL can significantly influence the carrier collection efficiency and carrier recombination rate simultaneously. The highest PCE of the thick HTL-based inverted perovskite solar cells is limited to be lower than $22 \%$ mainly due to the relatively low FF which is about $80 \%$. In general, the nanosecond time-resolved photoluminescence decaying curves show that the photogenerated hole collection efficiency at the perovskite/HTL interface is high when the PEDOT:PSS, PTAA and P3CT-X thin films are used as the HTL $[25,145,146]$, which means that the contact quality at the perovskite/HTL interface and hole mobility of the used HTL are both high. In other words, the limited PCE of the inverted perovskite solar cells is mainly due to the potential loss and carrier recombination, which can be used to explain the relatively low $\mathrm{V}_{\mathrm{OC}}$ and FF.

In recent years, it was found that the ultrathin PTAA polymers can be used to modify the surface of a roughed ITO thin film as the anode electrode, which can result in the high PCE of $18.11 \%$ [147]. The PCE of the ultrathin-PTAA-based inverted perovskite solar cells can be increased to be higher than $21 \%$ when the surface of the hydrophobic PTAA polymers is modified by using the bipolar organic molecules, such as PEAI and 3-(1-pyridinio)-i-propanesulfonate (PPS) [148,149]. The PCE increases from $18 \%$ to $21 \%$ with the decrease in the surface wettability of the ultrathin PTAA polymers, which is mainly due to the increases in the FF and $V_{O C}$. However, the increased FF and $V_{O C}$ cannot be completely explained as being due to the small grains of the perovskite crystalline thin films because the surface defect density is proportional to the grain size. The higher deep-level defect density results in the lower FF and $V_{O C}$ due to the non-radiative carrier recombination in the perovskite crystalline thin film [150]. The higher shallow-level defect density results in the higher $\mathrm{V}_{\mathrm{OC}}$ because the shallow-level defects can be considered as the dopants of the perovskite crystalline thin film [151]. Besides, the smaller grains can result in a smoother perovskite crystalline thin film, which can be completely covered with a 50 $\mathrm{nm}$ thick PCBM thin film. When the grain size of perovskite crystalline thin films is larger, 
the thickness of the used ETL must be thicker in order to form a perfect PCBM/perovskite planar heterojunction. The thicker ETL results in the higher electron recombination, thereby decreasing the FF and $\mathrm{V}_{\mathrm{OC}}$. In other words, the FF and $\mathrm{V}_{\mathrm{OC}}$ values are limited due to the trade-off between the grain size and surface roughness of the perovskite crystalline thin film.

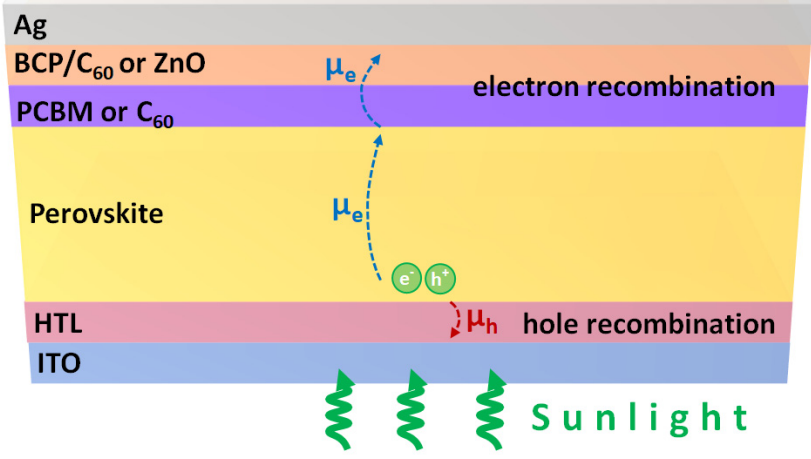

Figure 8. The main carrier transportations in the thick HTL/ETL-based inverted perovskite solar cell. HTL denotes hole transport layer. The ETL can be $\mathrm{BCP} / \mathrm{C}_{60} / \mathrm{PCBM}$ or $\mathrm{ZnO} / \mathrm{C}_{60}$.

In 2015, the edge-on P3CT-Na polymer was used to modify the surface of the ITO thin film as the anode electrode of the inverted perovskite solar cell [33]. The optimized thickness of the P3CT-Na polymers is about $4 \mathrm{~nm}$. Compared with the face-on PTAA polymers, the surface of edge-on P3CT-Na polymers is more wettable because the upward Na sites are hydrophilic. Besides, the upward Na sites of the P3CT-Na polymers can be considered as the nucleation sites during the formation of the perovskite crystalline thin film. Figure 9 presents the atomic-force microscopic images of an ITO/glass sample and a P3CT-Na/ITO/glass sample. In the ITO/glass sample, the size of islands ranges from $200 \mathrm{~nm}$ to $500 \mathrm{~nm}$. It is noted that the deposition of the P3CT-Na polymers does not influence the surface morphology of the ITO thin film, which means that the ultrathin P3CT$\mathrm{Na}$ polymer is formed. In the $\mathrm{MAPbI}_{3} / \mathrm{P} 3 \mathrm{CT}-\mathrm{Na} / \mathrm{ITO} /$ glass sample, the layered surface morphology shows that the $\mathrm{MAPbI}_{3}$ perovskite particles are sub-micrometer-sized single crystals, as shown in Figure 10. The grain size of the $\mathrm{MAPbI}_{3}$ crystalline thin film is similar to the island size of the ITO thin film, which means that the $\mathrm{MAPbI}_{3}$ single-crystalline grains grow on top of the edge-on P3CT-Na-modified ITO islands. The crystal orientation of the $\mathrm{MAPbI}_{3}$ crystalline thin film deposited on top of the P3CT-Na/ITO/glass is mainly along the (110) direction [152], which is consistent with the assumption that the upward $\mathrm{Na}$ sites of the P3CT-Na polymers are the nucleation sites during the formation of the $\mathrm{MAPbI}_{3}$ single-crystalline grains. 

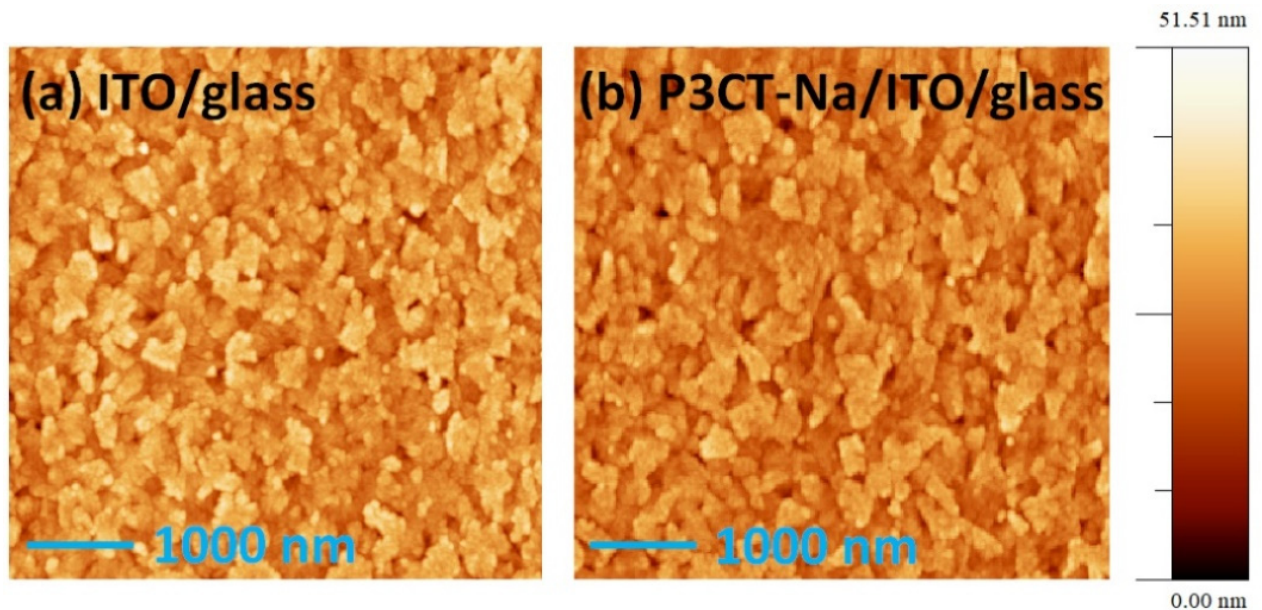

Figure 9. AFM images. (a) ITO/glass; (b) P3CT-Na/ITO/glass.
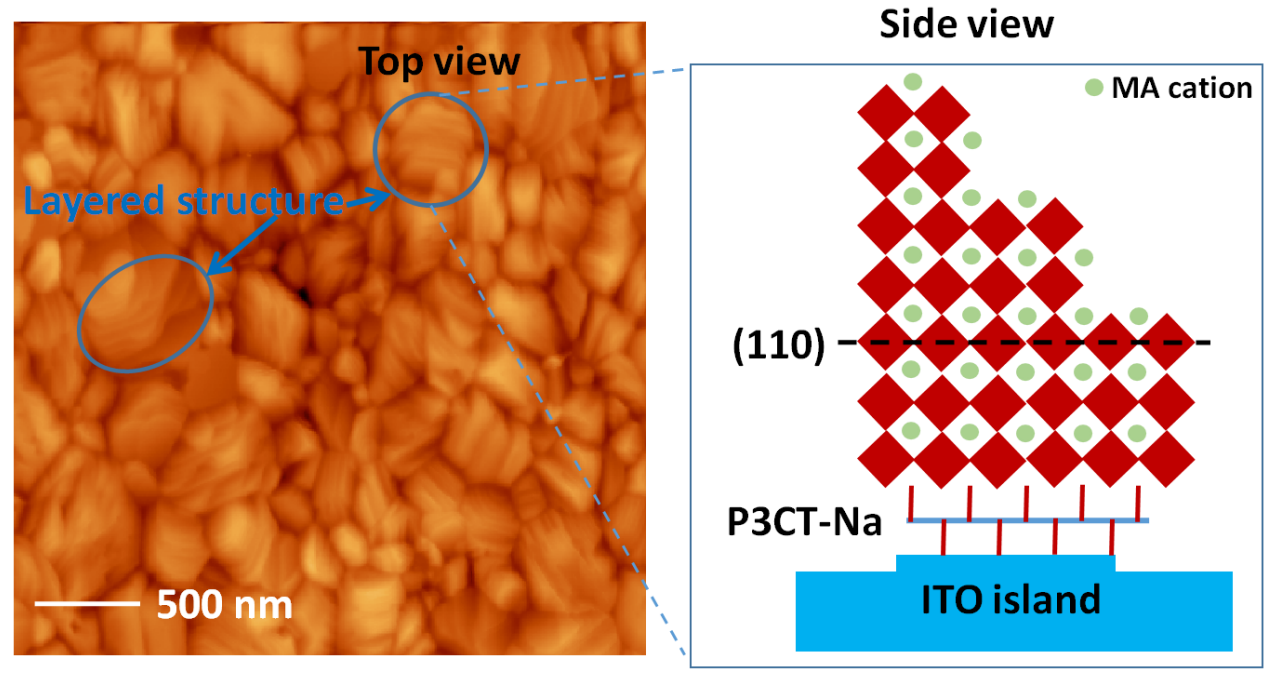

Figure 10. AFM image of a $\mathrm{MAPbI}_{3} / \mathrm{P} 3 \mathrm{CT}-\mathrm{Na} / \mathrm{ITO} /$ glass substrate and the schematic side view of the $\mathrm{MAPbI}_{3} / \mathrm{P} 3 \mathrm{CT}-\mathrm{Na} / \mathrm{ITO}$ trilayer structure.

\section{Roles of ETL in Inverted Perovskite Solar Cells}

To realize the highly efficient inverted perovskite solar cells, the photogenerated electrons in the light-absorbing layer must be collected effectively by the ETL. $\mathrm{C}_{60}$ - and $\mathrm{C}_{60}$-derivatives-based thin films are widely used as the ETL of the inverted perovskite solar cells. In general, the ETL is an electron collection layer, a hole blocking layer and a passivation layer, as shown in Figure 11a,c. Without the use of a capping layer (ETL), the surface defects of the perovskite crystal can trap the photogenerated electrons and holes, as shown in Figure 11b. When the surface defects are passivated by the capping layer (ETL), the delocalized electrons and delocalized holes become free carriers, thereby generating the photocurrents. In other words, the $C_{60}$ and $C_{60}$ derivatives can passivate the surface defects of the perovskite crystalline thin films when they are used as the ETL of the inverted perovskite solar cells. Figure 11d presents the molecular structures of $\mathrm{C}_{60}, \mathrm{PCBM}$ and ICBA. When the $\mathrm{C}_{60}$ molecules are used as the ETL, the surface electronrich defects of the perovskite crystalline thin films can be passivated due to the negative chargeability [153]. The negative chargeability of ICBA is better than that of $\mathrm{C}_{60}$ due to the higher electron affinity and non-spherical symmetric structure [154], which can be used to explain the improved photovoltaic performance of the inverted perovskite solar cells when the $\mathrm{C}_{60}$ is replaced by the $\mathrm{C}_{70}$ as the ETL [155]. When the PCBM molecules are used as the ETL, the surface electron-rich and electron-poor defects of the perovskite crystalline 
thin films can be passivated by the spherical fullerene and the oxygen of the functional group, respectively [29]. Besides, the molecular structure also dominates the formation of ordered molecular packing structure, which highly influences the electron mobility of the resultant ETL. Conceptually, the electron mobility of $\mathrm{C}_{60}$ thin films (ICBA thin films) is higher than that of ICBA thin films (PCBM thin films) due to the higher symmetry. In other words, there is a trade-off between the surface defect passivation and the formation of ordered molecular structure when the $\mathrm{C}_{60}$ derivatives are used as the ETL. On the other hand, the non-fullerene electron acceptor was used as an interlayer in between the ETL and perovskite crystalline thin film, which resulted in a high PCE of $22.09 \%$ mainly due to the reduced surface defects and improved carrier transport [156].

(a)

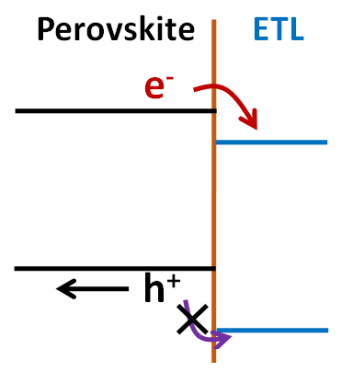

(d)

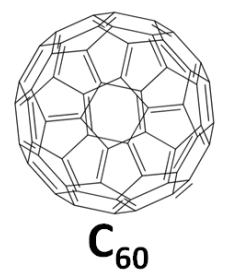

(b)

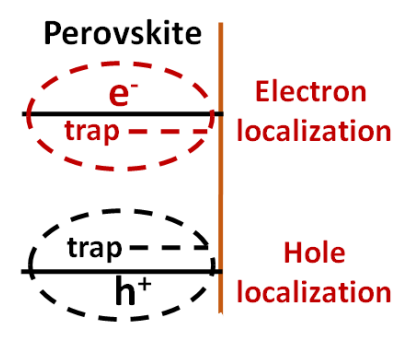

(c)

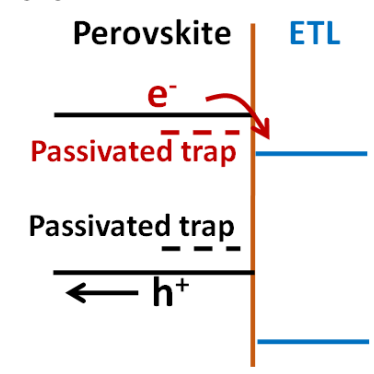

Figure 11. Energy diagrams and molecular structures. (a) Electron collection and hole blocking. (b) Trap-induced carrier localization. (c) Surface defect passivation. (d) $\mathrm{C}_{60}$, PCBM and ICBA.

\section{Challenges and Future Directions in Inverted Perovskite Solar Cells}

Through the understanding of the PEDOT:PSS, PTAA and P3CT-Na-based inverted perovskite solar cells, the main challenges and the possible future directions are discussed in the following subsections.

\subsection{PEDOT:PSS-Based Inverted Perovskite Solar Cells}

The PEDOT chains in the PEDOT:PSS thin films are p-type heavily doped conductive polymers, which can effectively collect the photogenerated holes from the perovskite thin films without the additional potential loss. However, the FF and $\mathrm{V}_{\mathrm{OC}}$ values of the PEDOT:PSS-based inverted perovskite solar cells are widely lower than $80 \%$ and $0.95 \mathrm{~V}$, respectively. The main reason is the formation of small perovskite grains on top of the hydrophilic PEDOT:PSS thin film, which forms high-density defects in the perovskite crystalline thin film, thereby resulting in the non-radiative carrier recombination. A postsolvent annealing process can be used to increase the grain size of the $\mathrm{MAPbI}_{3}$ thin films from $250 \mathrm{~nm}$ to $1000 \mathrm{~nm}$, which increases the JSC and FF of the resultant solar cells simultaneously [157]. However, the $\mathrm{J}_{\mathrm{SC}}$ hysteresis characteristic in the J-V curves can still be observed, which means the existence of halide vacancies inside the crystalline grains (point defects) in the bottom region of the perovskite thin film. Conceptually, the hydrogen cations in the sulfonic acid $\left(-\mathrm{SO}_{3} \mathrm{H}\right)$ groups can be substituted by the sodium cations with the addition of $\mathrm{NaOH}$ into the PEDOT:PSS/water solution [38], which results in the stable PSS polymers. In other words, the use of a stable PEDOT:PSS thin film with the dehydro- 
genation reaction can reduce the formation of halide vacancies in the perovskite crystalline thin film, which might improve the photovoltaic performance of the inverted perovskite solar cells. Besides, it is predicted that the dehydrogenation reaction of the PSS polymers in the PEDOT:PSS thin films can be performed by adding the organic halides, alkali halides or alkali hydroxide into the PEDOT:PSS/water solution. On the other hand, the doping concentration of PEDOT polymers can be largely increased by using the hydrogenosulfate as the dopant [158], which might increase the $\mathrm{V}_{\mathrm{OC}}$ of the resultant perovskite solar cells.

\subsection{PTAA-Based Inverted Perovskite Solar Cells}

In the best inverted perovskite solar cell, the ultrathin PTAA polymer is modified with the PEAI bipolar organic molecules, thereby forming the bridge between the PTAAmodified ITO thin film and the perovskite crystalline thin film, which results in the high PCE of $21.58 \%$ [70]. When the surface of the perovskite crystalline thin film is modified with the PEAI molecules, the PCE increases from $21.58 \%$ to $23.72 \%$ [70]. On the other hand, the PCE of the PPS-doped perovskite solar cells increases from $20.0 \%$ to $21.7 \%$ when the PPS molecule is used as the chemical bridge [149]. The PPS dopants might mainly distribute in the top region of the perovskite thin film and thereby passivate the surface defects [149]. Conceptually, the oxygens in the sulfonate acid group of the PPS molecules can passivate the halide vacancies or the interfacial organic cations at the grain boundaries of the perovskite crystalline thin film. In other words, the improved photovoltaic performance of the PTAAbased inverted perovskite solar cells is mainly due to the vacancy reduction in the bottom region and the defect passivation in the top region of the perovskite crystalline thin films. The photovoltaic performance of the best regular and inverted perovskite solar cells is listed in Table 2. Compared with the best regular perovskite solar cell, the lower PCE of the best inverted perovskite solar cell is due to the lower JSC. In other words, it is possible to increase the PCE of the PTAA-based inverted perovskite solar cells to be higher than $25 \%$ by using the $\alpha-\mathrm{FAPbI}_{3}$ crystalline thin film as the light-absorbing layer. However, the formation of a stable $\mathrm{FAPbI}_{3}$ crystalline thin film on top of the bipolar organic-molecule-modified ITO thin film will play the important role. It is noted that the grain sizes of the perovskite thin film deposited on top of the mesoporous $\mathrm{TiO}_{2} /$ compact $\mathrm{TiO}_{2} / \mathrm{FTO} /$ glass substrate can be $1000 \mathrm{~nm}$, which is larger than the grain size of the perovskite crystalline thin film deposited on top of the PEAI-modified ITO/glass substrate. In other words, the grain size of the $\mathrm{FAPbI}_{3}$ thin film deposited on top of the PEAI-modified ITO/glass substrate must be larger than the island size of the ITO thin film which ranges from $200 \mathrm{~nm}$ to $400 \mathrm{~nm}$ (see Figure 9). Fortunately, the substrate-induced small grain of the $\mathrm{MAPbI}_{3}$ crystalline thin film can be merged to be larger than $1000 \mathrm{~nm}$ via the formation of MA- $\mathrm{C}_{60}$-MA cations with the addition of $\mathrm{C}_{60}$ molecules into the $\mathrm{MAPbI}_{3}$ precursor solution [159]. It can be predicted that the $\mathrm{C}_{60}$-doped $\mathrm{FA}_{x} \mathrm{MA}_{1-x} \mathrm{PbI}_{3}$ thin films can also form merged grains via the formation of $\mathrm{C}_{60}-\mathrm{MA}-\mathrm{C}_{60}$ molecules at the grain boundaries. On the other hand, the PCE of the PTAA-based inverted perovskite solar cells is proportional to the molecular weight of the used PTAA $[160,161]$. However, there is a trade-off between the solubility and molecular weight of polymers [162], which might limit the highest molecular weight of the used PTAA polymers in the inverted perovskite solar cells.

Table 2. Photovoltaic performance of the best regular and inverted perovskite solar cells under one sun illumination (AM $\left.1.5 \mathrm{G}, 100 \mathrm{~W} / \mathrm{cm}^{2}\right)$.

\begin{tabular}{cccccccc}
\hline Structure Type & Perovskite & $\begin{array}{c}\text { Grain Size and } \\
\text { Thickness of } \\
\text { Perovskite }(\mathbf{n m})\end{array}$ & $\mathbf{V}_{\text {OC }}(\mathbf{V})$ & $\begin{array}{c}\text { JsC } \\
\left(\mathbf{m A} / \mathbf{c m}^{2}\right)\end{array}$ & FF (\%) & PCE (\%) & Ref. \\
\hline Regular & $\mathrm{FAPbI}_{3}$ & $2000 /$ none & 1.189 & 26.35 & 81.7 & 25.59 & {$[69]$} \\
Inverted & $(\mathrm{MAFA}) \mathrm{Pb}(\mathrm{ICl})_{3}$ & $350 / 550$ & 1.155 & 24.13 & 83.7 & 23.32 & {$[70]$} \\
\hline
\end{tabular}




\subsection{P3CT-X-Based Inverted Perovskite Solar Cells}

The P3CT-X polymers can be considered as the chemical bridges between the ITO thin film and perovskite crystalline thin film via the hydrophilic Na sites, which triggers the formation of edge-on P3CT-X polymers. X can be hydrogen ion, alkali metal cation or organic cation. Conceptually, the best candidate of the downward $\mathrm{X}$ site is a hydrogen ion because the carboxyl group can connect with the oxygen defect of the ITO thin film after hydrogenation reaction. When the upward X sites of the P3CT-X polymers are hydrogen ions, the $\mathrm{HI}$ molecules will be formed during the formation of $\mathrm{FAPbI}_{3}$ crystalline thin film on top of the P3CT-X-modified ITO thin film via the hydrogenation reaction, which can result in the formation of iodide vacancies. Ideally, the best candidate for the upward $X$ site is a FA cation which can be considered as the nucleation site during the formation of $\mathrm{FAPbI}_{3}$ crystalline thin film on top of the P3CT-X-modified ITO thin film, as shown in Figure 12a. In other words, the best P3CT-X polymer is an up-down asymmetric polymer, which can be a perfect p-type molecular bridge between the ITO thin film and $\mathrm{FAPbI}_{3}$ crystalline thin film, as shown in Figure 12b. However, the surface oxygen defect density of the ITO thin film must be related to the spacing between adjacent downward carboxyl groups. The d-spacing value of the $\mathrm{FAPbI}_{3}$ crystal along the (110) direction is larger than the spacing between adjacent upward carboxyl groups. To reduce the mismatch between the d-spacing of the perovskite crystal and the spacing between adjacent upward carboxyl groups of the $\mathrm{P} 3 \mathrm{CT}$ polymer, a $\mathrm{FAPbCl}_{3}$ crystal of a $\mathrm{FAPbBr}_{3}$ crystal can be inserted as the buffer layer due to the shorter lattice constant.

(a)

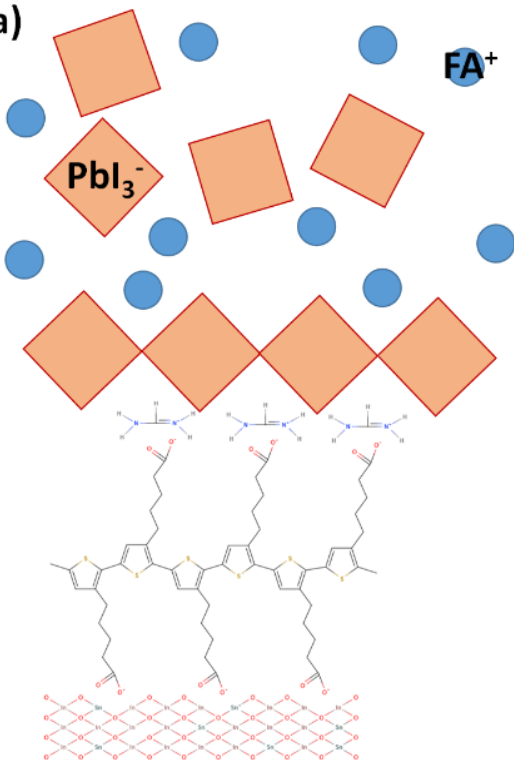

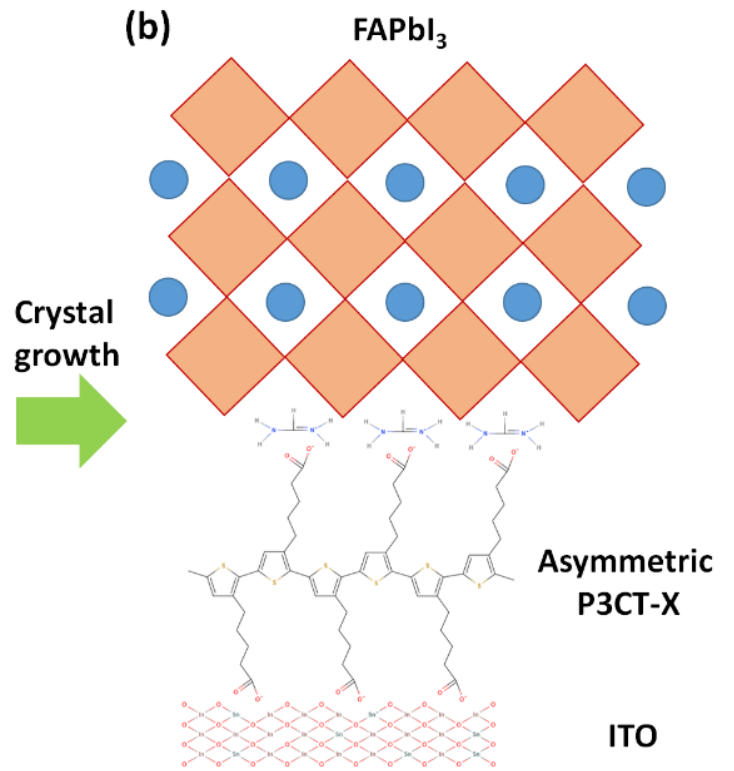

Figure 12. Formation ofsingle crystalline $\mathrm{FAPbI}_{3}$ perovskite on top of the asymmetric P3CT-Xmodified ITO thin film. (a) Nucleation. (b) Crystal growth.

\subsection{An Ideal Polymer-MTL-Based Inverted Perovskite Solar Cell}

Figure 13 presents the ideal polymer-based inverted perovskite solar cell. The edge-on or face-on polymers have to form an ultrathin hole modification layer (HML) on top of the roughened ITO thin film. Then, the solution-processed perovskite crystalline thin film can be grown on top of the ultrathin conjugated polymer-modified ITO thin film, which forms single crystalline perovskite grains (see Figure 10), thereby resulting in the extremely high $\mathrm{V}_{\mathrm{OC}}$ and $\mathrm{FF}$ (see Tables 1 and 2). In other words, the formation of molecular connection between the perovskite and HML (see Figure 12) results in the intrinsically high photogenerated hole collection efficiency. To increase the $\mathrm{J}_{\mathrm{SC}}$, the optical bandgap of the light-absorbing layer used in the highly efficient inverted perovskite solar cells must be decreased by using the $\alpha-\mathrm{FAPbI}_{3}$ crystalline thin film [69]. It is noted that grain size of 
perovskite crystalline thin films used in the highly efficient perovskite solar cells ranges from $300 \mathrm{~nm}$ to $2000 \mathrm{~nm}$, which indicates that the photogenerated electrons can be collected effectively when the surface defects of the single crystalline perovskite grains are passivated by the capping layer (small molecular-based ETL). Besides, the thickness of the perovskite crystalline thin film is less than $600 \mathrm{~nm}$ due to the high absorption coefficients in the visible to near-infraredwavelength range. According to Table 2, it is predicated that the PCE of the polymer-HTL-based inverted perovskite solar cell can be increased from $23.32 \%$ to $25.47 \%$ by increasing the $\mathrm{JSC}_{\mathrm{SC}}$ value from $24.13 \mathrm{~mA} / \mathrm{cm}^{2}$ to $26.35 \mathrm{~mA} / \mathrm{cm}^{2}$.

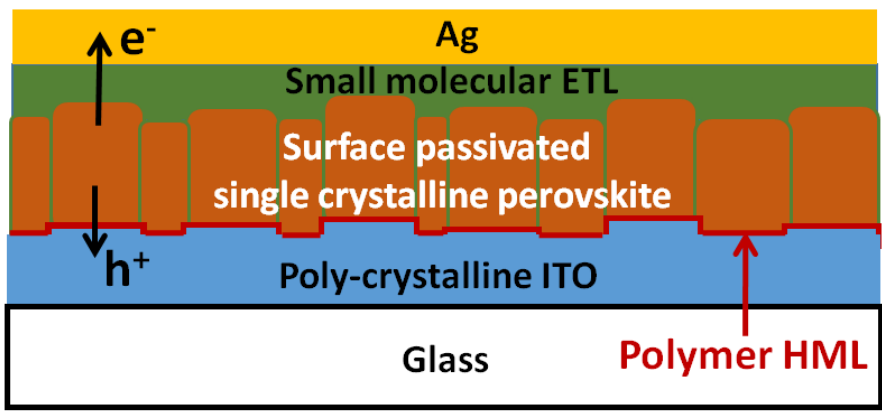

Figure 13. The device structure of an ideal polymer-HML-based inverted perovskite solar cell.

\section{Conclusions}

In summary, we have reviewed the three main p-type polymers (PEDOT:PSS, PTAA and P3CT-X) used in the inverted perovskite solar cells as the HTL or HML. In the PEDOT:PSS thin-film-based perovskite solar cells, it is predicted that the surface defects and point defects of the perovskite crystalline thin films can be reduced by adding p-type hydrophobic conjugated small molecules and by replacing the hydrogen cations of the PSS polymers with alkali metal ions, respectively, which can increase the $\mathrm{V}_{\mathrm{OC}}$ and FF of the resultant solar cells. In the ultrathin face-on PTAA polymers-based perovskite solar cells, the contact qualities at the perovskite/HML interface and the ETL/perovskite interface can be improved by using the bipolar organic molecules, which increases the $\mathrm{V}_{\mathrm{OC}}$, JSC and FF simultaneously. In other words, it is worthwhile to develop new bipolar organic molecules to replace PEAI and PPS molecules as the chemical bridges at the perovskite/HML interface and the ETL/perovskite interface. In the ultrathin edge-on P3CT-X-polymer-based perovskite solar cells, it is predicted that the perovskite crystalline thin film and the ITO thin film can be perfectly connected with the up-down asymmetric P3CT- $X$ polymers. Besides, the substrate-induced sub-micrometer-sized $\mathrm{FA}_{x} \mathrm{MA}_{1-x} \mathrm{PbI}_{3}$ grains can be merged to form micrometer-sized grains via the formation of the MA- $\mathrm{C}_{60}-\mathrm{MA}$ cations with the addition of $\mathrm{C}_{60}$ molecules into the perovskite precursor solution, which can reduce the potential loss in the light-absorbing layer, thereby increasing the $\mathrm{V}_{\mathrm{OC}}$ of the resulting solar cells.

Author Contributions: Conceptualization, S.H.C.; data curation, Q.B.K., J.-R.W. and C.-C.L.; formal analysis, Q.B.K.; writing—original draft preparation, Q.B.K.; writing—review and editing, S.H.C. All authors have read and agreed to the published version of the manuscript.

Funding: This research was funded by Ministry of Science and Technology, Taiwan. Grant numbers are MOST 110-2112-M-033-008-MY3 and MOST 110-2112-M-033-012.

Data Availability Statement: Not applicable.

Conflicts of Interest: The authors declare no conflict of interest.

\section{References}

1. Lenz, A.; Kariis, H.; Pohl, A.; Persson, P.; Ojamae, L. The electronic structure and reflectivity of PEDOT:PSS from density functional theory. Chem. Phy. 2011, 384, 44-51. [CrossRef]

2. $\quad$ Feng, Z.-H.; Hou, Y.-B.; Shi, Q.-M.; Qin, L.-F.; Li, Y.; Zhang, L.; Liu, X.-J.; Teng, F.; Wang, Y.-S.; Xia, R.-D. Polymer solar cells based on a PEDOT:PSS layer spin-coated under the action of an electric field. Chin. Phys. B 2010, 19, 038601. 
3. Chang, S.H.; Chiang, C.-H.; Kao, F.-S.; Tien, C.-L.; Wu, C.-G. Unraveling the enhanced electrical conductivity of PEDOT:PSS thin films for ITO-free organic photovoltaics. IEEE Photonics J. 2014, 6, 8400307.

4. Xu, B.; Gopalan, S.-A.; Gopalan, A.-I.; Muthuchamy, N.; Lee, K.-P.; Lee, J.-S.; Jiang, Y.; Lee, S.-W.; Kim, S.W.; Kim, J.-S.; et al Functional solid additive modified PEDOT:PSS as an anode buffer layer for enhanced photovoltaic performance and stability in polymer solar cells. Sci. Rep. 2017, 7, 45079. [CrossRef] [PubMed]

5. Wei, W.; Wang, H.; Hu, Y.H. A review on PEDOT-based counter electrodes for dye-sensitized solar cells. Int. J. Energy Res. 2014, 38, 1099-1111. [CrossRef]

6. Bourarissa, A.; Gueddim, A.; Bouarissa, N.; Djellali, S. Band structure and optical properties of polyaniline polymer material. Polym. Bull. 2018, 75, 3023-3033. [CrossRef]

7. Moule, A.J.; Jung, M.-C.; Rochester, C.W.; Tress, W.; LaGrange, D.; Jacobs, I.E.; Mauger, S.A.; Rail, M.D.; Lin, O.; Bilsky, D.J.; et al. Mixed interlayers at the interface between PEDOT:PSS and conjugated polymers provide charge transport control. J. Mater. Chem. C 2015, 3, 2664-2676. [CrossRef]

8. Hu, L.; Song, J.; Yin, X.; Su, Z.; Li, Z. Research progress on polymer solar cells based on PEDOT:PSS electrodes. Polymers 2020, 12, 145. [CrossRef]

9. Bejbouji, H.; Vignau, L.; Miane, J.L.; Dang, M.-T.; Oaulim, E.M.; Harmouchi, M.; Mouhsen, A. Polyaniline as hole injection layer on organic photovoltaic cells. Sol. Energy Mater. Sol. Cells 2010, 94, 176-181. [CrossRef]

10. Dwiveid, G.; Munjal, G.; Bhaskarwar, A.N.; Chaudhary, A. Dye-sensitized solar cells with polyaniline: A review. Inorg. Chem. Commun. 2022, 135, 109087. [CrossRef]

11. Menke, S.M.; Ran, N.A.; Bazan, G.C.; Friend, R.H. Understanding energy loss in organic solar cells: Toward a new efficiency regime. Joule 2018, 2, 25-35. [CrossRef]

12. Chen, L.X. Organic Solar Cells: Recent progress and challenges. ACS Energy Lett. 2019, 4, 2537-2539. [CrossRef]

13. Leblebici, S.Y.; Chen, T.L.; Olalde-Velasco, P.; Yang, W.; Ma, B. Reducing exciton binding energy by increasing thin film permittivity: An effective approach to enhance exciton separation efficiency in organic solar cells. ACS Appl. Mater. Interfaces 2013, 20, 10105-10110. [CrossRef] [PubMed]

14. Zhu, L.; Yi, Y.; Wei, Z. Exciton binding energies of nonfullerene small molecule acceptors: Implication for exciton dissociation driving forces in organic solar cells. J. Phys. Chem. C 2018, 122, 22309-22316. [CrossRef]

15. Giuliano, G.; Bonasera, A.; Scopelliti, M.; Martino, D.C.; Fiore, T.; Pignataro, B. Boosting the performance of one-step solutionprocessed perovskite solar cells using a natural monterpene alcohol as a green solvent additive. ACS Appl. Electron. Mater. 2021, 3, 1813-1825. [CrossRef]

16. Jeon, N.J.; Noh, J.H.; Kim, Y.C.; Yang, W.S.; Ryu, S.; Seok, S.I. Solvent engineering for high-performance inorganic-organic hybrid perovskite solar cells. Nat. Mater. 2014, 13, 897-903. [CrossRef]

17. Chen, H. Two-step sequential deposition of organometal halide perovskite for photovoltaic application. Adv. Funct. Mater. 2017, 27, 1605654. [CrossRef]

18. Vaynzof, Y. The future of perovskite photovoltaics-thermal evaporation or solution processing? Adv. Energy Mater. 2020, 10, 2003073. [CrossRef]

19. Ouyang, Z.; Yang, M.; Whitaker, J.B.; Li, D.; van Hest, M.F.A.M. Toward scalable perovskite solar modules using blade coating and rapid thermal processing. ACS Appl. Energy Mater. 2020, 3, 3714-3720. [CrossRef]

20. Jeng, J.-Y.; Chiang, Y.-F.; Lee, M.-H.; Peng, S.-R.; Guo, T.-F.; Chen, P.; Wen, T.-C. $\mathrm{CH}_{3} \mathrm{NH}_{3} \mathrm{PbI}_{3}$ perovskite/fullerene planarheterojunction hybrid solar cells. Adv. Mater. 2013, 25, 3727-3732. [CrossRef]

21. Chang, S.H.; Lin, K.-F.; Chiu, K.Y.; Tsai, C.-L.; Cheng, H.-M.; Chen, W.-N.; Chen, S.-H.; Wu, C.-G. Improving the efficiency of $\mathrm{CH}_{3} \mathrm{NH}_{3} \mathrm{PbI}_{3}$ based photovoltaics by tuning the work function of PEDOT:PSS hole transport layer. Sol. Energy 2015, 122, 892-899. [CrossRef]

22. Chen, C.-C.; Chang, S.H.; Chen, L.-C.; Cheng, H.-M.; Wu, W.-T.; Chuang, C.L.; Tseng, Z.-L.; Wu, C.-G. Improving the efficiency of inverted mixed-organic-cation perovskite absorber based photovoltaics by tailing the surface roughness of PEDOT:PSS thin film. Sol. Energy 2016, 135, 445-451. [CrossRef]

23. Chang, S.H.; Chen, W.-N.; Chen, C.-C.; Yeh, S.-C.; Cheng, H.-M.; Tseng, Z.-L.; Chen, L.-C.; Chiu, K.Y.; Chen, C.-T.; Chen, S.-H.; et al. Manipulating the molecular structure of PEDOT chains through controlling the viscosity of PEDOT:PSS solution to improve photovoltaic performance of $\mathrm{CH}_{3} \mathrm{NH}_{3} \mathrm{PbI}_{3}$ solar cells. Sol. Energy. Mater. Sol. Cells 2017, 161, 7-13. [CrossRef]

24. Xia, Y.; Yan, G.; Lin, J. Review on tailoring PEDOT:PSS layer for improved device stability of perovskite solar cells. Nanomaterials 2021, 11, 3119. [CrossRef] [PubMed]

25. Lin, K.-F.; Chang, S.H.; Wang, K.-H.; Chen, H.-M.; Lee, K.-M.; Chen, S.-H.; Wu, C.-G. Unraveling the high performance of tri-iodide perovskite absorber based photovoltaics with a non-polar solvent washing treatment. Sol. Energy Mater. Sol. Cells 2015, 141, 309-314. [CrossRef]

26. Chang, S.H.; Lin, K.-F.; Cheng, H.-M.; Chen, C.-C.; Wu, W.-T.; Chen, S.-H.; Wu, C.-G. Influence of organic cations on highperformance $\mathrm{CH}_{3} \mathrm{NH}_{3} \mathrm{PbI}_{3}$ based photovoltaics. Sol. Energy Mater. Sol. Cells 2016, 145, 375-381. [CrossRef]

27. Chen, C.-C.; Chang, S.H.; Chen, L.-C.; Cheng, H.-M.; Tseng, Z.-L.; Wu, C.-G. Manipulating multicrystalline grain size in $\mathrm{CH} 3 \mathrm{NH} 3 \mathrm{PbI} 3$ thin films for application in photovoltaics. Sol. Energy 2016, 139, 518-523. [CrossRef]

28. Li, Y.; Meng, L.; Yang, Y.; Xu, G.; Hong, Z.; Chen, Q.; You, J.; Li, G.; Yang, Y.; Li, Y. High-efficiency robust perovskite solar cells on ultrathin flexible substrates. Nat. Commun. 2016, 7, 10214. [CrossRef] 
29. Chang, S.H.; Chiang, C.-C.; Chen, L.-C.; Tien, C.-L.; Cheng, H.-M.; Huang, W.-C.; Lin, H.-Y.; Chen, S.-H.; Wu, C.-G. Unraveling the multifunctional capabilities of PCBM thin films in inverted-type CH3NH3PbI3 based photovoltaics. Sol. Energy Mater. Sol. Cells 2017, 169, 40-46. [CrossRef]

30. Cho, A.-N.; Park, N.-G. Impact of interfacial layers in perovskite solar cells. ChemSusChem 2017, 10, 3687-3704. [CrossRef]

31. Wang, Q.; Bi, C.; Huang, H. Doped hole transport layer for efficiency enhancement in planar heterojunction organolead trihalide perovskite solar cells. Nano Energy 2015, 15, 275-280. [CrossRef]

32. Hu, M.; Bi, C.; Yuan, Y.; Bai, Y.; Huang, H. Stabilized wide bandgap MAPbBr $\mathrm{I}_{3-x}$ perovskite by enhanced grain size and improved crystallinity. Adv. Sci. 2016, 3, 1500301. [CrossRef] [PubMed]

33. Li, X.; Liu, X.; Wang, X.; Zhao, L.; Jiu, T.; Fang, J. Polyelectrolyte based hole-transporting materials for high performance solution processed planar perovskite solar cells. J. Mater. Chem. A 2015, 3, 15024-15029. [CrossRef]

34. Li, S.; He, B.; Xu, J.; Lu, H.; Jiang, J.; Zhu, J.; Kan, Z.; Zhu, L.; Wu, F. Highly efficient inverted perovskite solar cells incorporating P3CT-Rb as a hole transport layer to achieve a large open circuit voltage of 1.144 V. Nanoscale 2020, 12, 3686-3691. [CrossRef]

35. Glowienka, D.; Zhang, D.; Giacomo, F.D.; Najafi, M.; Veenstra, S.; Szmytkowski, J.; Galagan, Y. Role of surface recombination in perovskite solar cells at the interface of $\mathrm{HTL} / \mathrm{CH}_{3} \mathrm{NH}_{3} \mathrm{PbI}_{3}$. Nano Energy 2020, 67, 104186. [CrossRef]

36. Haddad, J.; Krogmeier, B.; Klingebiel, B.; Kruckemeier, L.; Melhem, S.; Liu, Z.; Hupkes, J.; Mathur, S.; Kirchartz, T. Analyzing interface recombination in lead-halide perovskite solar cells with organic and inorganic hole-transport layers. Adv. Mater. Interfaces 2020, 7, 2000366. [CrossRef]

37. Raoui, Y.; Ez-Zahraouy, H.; Kazim, S.; Ahmad, S. Energy level engineering of charge selective contact and halide perovskite by modulating band offset: Mechanistic insights. J. Energy Chem. 2021, 54, 822-829. [CrossRef]

38. Chin, Y.-C.; Daboczi, M.; Henderson, C.; Luke, J.; Kim, J.-S. Suppressing PEDOT:PSS doping-induced interfacial recombination loss in perovskite solar cells. ACS Energy Lett. 2022, 7, 560-568. [CrossRef]

39. Lee, H.; Rhee, S.; Kim, J.; Lee, C.; Kim, H.J. Surface coverage enhancement of a mixed halide perovskite film by using an UV-ozone treatment. Korean Phys. Soc. 2016, 69, 406-411. [CrossRef]

40. Lee, K.-M.; Chen, C.-C.; Chen, L.-C.; Chang, S.H.; Chen, K.-S.; Yeh, S.-C.; Chen, C.-T.; Wu, C.-G. Thickness effects of the thermally evaporated $\mathrm{C}_{60}$ thin films on regular-type $\mathrm{CH}_{3} \mathrm{NH}_{3} \mathrm{PbI}_{3}$ based solar cells. Sol. Energy. Mater. Sol. Cells 2017, 164, 13-18. [CrossRef]

41. Islam, M.B.; Yanagida, M.; Shirai, Y.; Nabetani, Y.; Miyano, K. NiO hole transport layer for perovskite solar cells with improved stability and reproducibility. ACS Omega 2017, 2, 2291-2299. [CrossRef] [PubMed]

42. Yu, Z.-K.; Fu, W.-F.; Liu, W.-Q.; Zhang, Z.-Q.; Liu, Y.-J.; Yan, J.-L.; Ye, T.; Yang, W.-T.; Li, H.-Y.; Chen, H.-Z. Solution-processed $\mathrm{CuO}_{x}$ as an efficient hole-extraction layer for inverted planar heterojunction perovskite solar cells. Chin. Chem. Lett. 2017, 28, 13-18. [CrossRef]

43. Xue, Q.; Bai, Y.; Liu, M.; Xia, R.; Hu, Z.; Chen, Z.; Jiang, X.-F.; Huang, F.; Yang, S.; Matsuo, Y.; et al. Dual interfacial modifications enable high performance semitransparent perovskite solar cells with large open circuit voltage and fill factor. Adv. Energy Mater. 2017, 7, 1602333. [CrossRef]

44. Chen, W.; Zhou, Y.; Chen, G.; Wu, Y.; Tu, B.; Liu, F.-Z.; Huang, L.; Na, A.M.C.; Djurisic, A.B.; He, Z. Alkali chlorides for the suppression of the interfacial recombination in inverted planar perovskite solar cells. Adv. Energy Mater. 2019, 9, 1803872. [CrossRef]

45. Hsu, H.-L.; Jiang, B.-H.; Lan, J.-M.; Wu, C.-H.; Jeng, R.-J.; Chen, C.-P. Small molecules with controllable molecular weights passivate surface defects in air-stable p-i-n perovskite solar cells. Adv. Electron. Mater. 2021, 7, 2000870. [CrossRef]

46. Chang, Y.-M.; Li, C.-W.; Lu, Y.-L.; Wu, M.-S.; Li, H.; Lin, Y.-S.; Lu, C.-W.; Chen, C.-P.; Chang, Y.J. Spherical hole-transporting interfacial layer passivated defect for inverted $\mathrm{NiO}_{\mathrm{x}}$-based planar perovskite solar cells with high efficiency of over $20 \%$. ACS Appl. Mater. Interfaces 2021, 13, 6450-6460. [CrossRef] [PubMed]

47. Ma, F.; Zhao, Y.; Li, J.; Zhang, X.; Gu, H.; You, J. Nickel oxide for inverted structure perovskite solar cells. J. Energy Chem. 2021, 52, 393-411. [CrossRef]

48. Xu, X.; Ma, C.; Cheng, Y.; Xie, Y.-M.; Yi, X.; Gautam, B.; Chen, S.; Li, H.-W.; Lee, C.-S.; So, F.; et al. Ultraviolet-ozone surface modification for non-wetting hole transport materials based inverted planar perovskite solar cells with efficiency exceeding $18 \%$. J. Power Sources 2017, 360, 157-165. [CrossRef]

49. Wang, Y.; Li, M.; Li, H.; Lan, Y.; Zhou, X.; Li, C.; Hu, X.; Song, Y. Patterned wettability surface for competition-driving large-grained perovskite solar cells. Adv. Energy Mater. 2019, 9, 1900838. [CrossRef]

50. Wang, T.; Xie, M.; Abbasi, S.; Cheng, Z.; Liu, H.; Shen, W. High efficiency perovskite solar cells with tailorable surface wettability by surfactant. J. Power Sources 2020, 448, 227584. [CrossRef]

51. Chen, L.-C.; Chen, C.-C.; Chang, S.H.; Lee, K.-L.; Tseng, Z.-L.; Chen, S.-H.; Kuo, H.-C. Formation and characterization of preferred oriented perovskite thin films on single-crystalline substrates. Mater. Res. Express 2018, 5, 066403. [CrossRef]

52. Wei, W.; Zhang, Y.; Xu, Q.; Wei, H.; Fang, Y.; Wang, Q.; Deng, Y.; Li, T.; Gruverman, A.; Cao, L.; et al. Monolithic integration of hybrid perovskite single crystals with heterogeneous substrate for highly sensitive X-ray imaging. Nat. Photonics 2017, 11, 315-321. [CrossRef]

53. Pan, L.; Feng, Y.; Kandlakunta, P.; Huang, J.; Cao, L.R. Performance of perovskite $\mathrm{CsPbBr}_{3}$ single crystal detector for gamma-ray detection. IEEE Trans. Nucl. Sci. 2020, 67, 443-449. [CrossRef]

54. Chiang, C.-H.; Wu, C.-G. Bulk heterojunction perovskite-PCBM solar cells with high fill factor. Nat. Photonics 2016, 10, 196-200. [CrossRef] 
55. Chen, L.-C.; Tseng, Z.-L.; Huang, J.-K.; Chen, C.-C.; Chang, S.H. Fullerene-based electron transport layers for semi-transparent $\mathrm{MAPbI}_{3}$ perovskite films in planar perovskite solar cells. Coating 2016, 6, 53. [CrossRef]

56. Liu, B.; Cui, R.; Huang, H.; Guo, X.; Dong, J.; Yao, H.; Li, Y.; Zhao, D.; Wang, J.; Zhang, J.; et al. Elucidating the mechanisms underlying PCBM enhancement of $\mathrm{CH}_{3} \mathrm{NH}_{3} \mathrm{PbI}_{3}$ perovskite solar cells using GIXRD and XAFS. J. Mater. Chem. A 2020, 8, 3145-3153. [CrossRef]

57. Xu, C.; Liu, Z.; Lee, E.-C. High-performance inverted planar perovskite solar cells using a pristine fullerene mixture as an electron-transport layer. J. Mater. Chem. C 2019, 7, 6956-6963. [CrossRef]

58. Chang, S.H.; Wong, S.-D.; Huang, H.-Y.; Yuan, C.-T.; Wu, J.-R.; Chiang, S.-E.; Tseng, Z.-L.; Chen, S.-H. Effects of the washingenhanced nucleation process on the material properties and performance of perovskite solar cells. J. Alloys Compd. 2019, 808, 151723. [CrossRef]

59. Chiang, S.-E.; Wu, J.-R.; Cheng, H.-M.; Hsu, C.-L.; Shen, J.-H.; Yuan, C.-T.; Chang, S.H. Origins of the s-shape characteristic in J-V curve of inverted-type perovskite solar cells. Nanotechnology 2020, 31, 115403. [CrossRef]

60. Zhong, H.; Zhou, R.; Wu, X.; Lin, X.; Wang, Y.; Li, Q.; Zhou, H. Investigation of the s-shaped current-voltage curve in high open-circuit voltage ruddlesden-popper perovskite solar cells. Front. Energy Res. 2021, 9, 689657. [CrossRef]

61. Liu, X.; Yu, H.; Yan, L.; Dong, Q.; Wan, Q.; Zhou, Y.; Song, B.; Li, Y. Triple cathode buffer layers composed of PCBM, C 60 , and LiF for high-performance planar perovskite solar cells. ACS Appl. Mater. Interfaces 2015, 7, 6230-6237. [CrossRef]

62. Shibayama, N.; Kanda, H.; Kim, T.W.; Segawa, H.; Ito, S. Design of BCP buffer layer for inverted perovskite solar cells using ideal factor. APL Mater. 2019, 7, 031117. [CrossRef]

63. Chang, S.H.; Tseng, P.-C.; Chiang, S.-E.; Wu, J.-R.; Chen, Y.-T.; Chen, C.-J.; Yuan, C.-T.; Chen, S.-H. Structural, optical and excitonic properties of $\mathrm{MA}_{x} \mathrm{Cs}_{1-\mathrm{x}} \mathrm{Pb}\left(\mathrm{I}_{\mathrm{x}} \mathrm{Br}_{1-\mathrm{x}}\right)_{3}$ alloy thin films and their application in solar cells. Sol. Energy Mater. Sol. Cells 2020, 210, 110478. [CrossRef]

64. Chiang, S.-E.; Chandel, A.; Thakur, D.; Chen, Y.-T.; Lin, P.-C.; Wu, J.-R.; Cai, K.-B.; Kassou, S.; Yeh, J.-M.; Yuan, C.-T.; et al. On the role of solution-processed bathocuproine in high-efficiency inverted perovskite solar cells. Sol. Energy 2021, 218, 142-149. [CrossRef]

65. Granas, O.; Vinichenko, D.; Kaxiras, E. Establishing the limits of efficiency of perovskite solar cells form first principles modeling. Sci. Rep. 2016, 6, 36108. [CrossRef] [PubMed]

66. Pazos-Outon, L.M.; Xiao, T.P.; Yablonovitch, E. Fundamental Efficiency limit of lead iodide perovskite solar cells. J. Phys. Chem. Lett. 2018, 9, 1703-1711. [CrossRef]

67. Jacobsson, J.J.; Correa-Baena, J.-P.; Pazoki, M.; Saliba, M.; Schenk, K.; Gratzel, M.; Hagfeldt, A. Exploration of the compositional space for mixed lead halogen perovskites for high efficiency solar cells. Energy Environ. Sci. 2016, 9, 1706-1724. [CrossRef]

68. Qaid, S.M.H.; Al Sobaie, M.S.; Majeed Khan, M.A.; Bedja, I.M.; Alharbi, F.H.; Nazeeruddin, M.K.; Aldwayyan, A.S. Band-gap tuning of lead halide perovskite using a single step spin-coating deposition process. Mater. Lett. 2016, 164, 498-501. [CrossRef]

69. Jeong, J.; Kim, M.; Seo, J.; Lu, H.; Ahlawat, P.; Mishra, A.; Yang, Y.; Hope, M.A.; Eickemeyer, F.T.; Kim, M.; et al. Pseudo-halide anion engineering for $\alpha-\mathrm{FAPbI}_{3}$ perovskite solar cells. Nature 2021, 592, 381-385. [CrossRef]

70. Degani, M.; An, Q.; Albaladejo-Siguan, M.; Hofstetter, Y.J.; Cho, C.; Paulus, F.; Grancini, G.; Vaynzof, Y. 23.7\% efficient inverted perovskite solar cells by dual interfacial modification. Sci. Adv. 2020, 7, eabj7930. [CrossRef]

71. Burschka, J.; Pellet, N.; Moon, S.-J.; Humphry-Baker, R.; Gao, P.; Nazzruddin, M.K.; Gratzel, M. Sequential deposition as a route to high-performance perovskite-sensitized solar cells. Nature 2013, 499, 316-319. [CrossRef] [PubMed]

72. Qiu, W.; Ray, A.; Jaysankar, M.; Merckx, T.; Bastos, J.P.; Cheyns, D.; Gehlhaar, R.; Poormans, J.; Heremans, P. An interdiffusion method for highly performing cesium/formanidinium double cation perovskites. Adv. Funct. Mater. 2017, 27, 1700920. [CrossRef]

73. Tripathi, N.; Yanagida, M.; Shirai, Y.; Miyano, K. Improved performance of planar perovskite devices via inclusion of ammonium acid iodide (AAI) derivatives using a two step inter-diffusion process. J. Mater. Chem. C 2019, 7, 3447-3451. [CrossRef]

74. Chang, S.H.; Huang, W.-C.; Chen, C.-C.; Chen, S.-H.; Wu, C.-G. Effects of anti-solvent (iodobenzene) volume on the formation of $\mathrm{CH}_{3} \mathrm{NH}_{3} \mathrm{PbI}_{3}$ thin films and their application in photovoltaic cells. Appl. Surf. Sci. 2018, 445, 24-29. [CrossRef]

75. Li, C.-Y.; Liao, Y.-S.; Thakur, D.; Chandel, A.; Chiang, S.-E.; Wu, J.-R.; Lee, P.-H.; Tsai, C.-L.; Yang, C.-C.; Zhong, Y.-L.; et al. Anti-solvent mixture-mediated reduction of photocurrent hysteresis in high-impurity perovskite precursor based $\mathrm{MAPbI}_{3}$ solar cells. Sol. Energy 2021, 2014, 86-92. [CrossRef]

76. Chandel, A.; Wu, J.-R.; Thakur, D.; Kassou, S.; Chaing, S.-E.; Cheng, K.-R.; Li, C.-Y.; Yen, Y.-S.; Chen, S.-H.; Chang, S.H. Improvement of interfacial contact for efficient $\mathrm{PCBM} / \mathrm{MAPbI}_{3}$ planar heterojunction solar cells with a binary antisolvent mixture treatment. Nanotechnology 2021, 32, 485401. [CrossRef]

77. Chen, C.-Y.; Lin, H.-Y.; Chiang, K.-M.; Tsai, W.-L.; Huang, Y.-C.; Tsao, C.-S.; Lin, H.-W. All-vaccum-deposition stoichiometrically balanced inorganic cesium lead halide perovskite solar cells with stabilized efficiency exceeding 11\%. Adv. Mater. 2017, 29, 1605290. [CrossRef]

78. Rob, M.; Gil-Escrig, L.; Al-Ashouri, A.; Tockhorn, P.; Jost, M.; Rech, B.; Albrecht, S. Co-evaporated p-i-n perovskite solar cells beyond $20 \%$ efficiency: Impact of substrate temperature and hole-transport layer. ACS Appl. Mater. Interfaces 2020, 12, 39261-39272.

79. Abzieher, T.; Feeney, T.; Schackmar, F.; Donie, Y.J.; Hossain, I.M.; Schwenzer, J.A.; Hellmann, T.; Mayer, T.; Powalla, M.; Paetzold, U.W. From groundwork to efficient solar cells: On the importance of the substrate material in co-evaporated perovskite solar cells. Adv. Funct. Mater. 2021, 31, 2104482. [CrossRef] 
80. Leguy, A.M.A.; Azarhoosh, P.; Alonso, M.I.; Campoy-Quiles, M.; Weber, O.J.; Yao, J.; Bryant, D.; Weller, M.T.; Nelson, J.; Walsh, A.; et al. Experimental and theoretical optical properties of methylammonium lead halide perovskites. Nanoscale 2016, 8, 6317-6327. [CrossRef]

81. El-Ghtami, H.; Laref, A.; Laref, S. Electronic and optical behaviors of methylammonium and formamidinium lead trihalide perovskite materials. J. Mater. Sci. Mater. Electron. 2019, 30, 711-720. [CrossRef]

82. Chang, J.; Chen, H.; Yuan, H.; Wang, B.; Chen, X. The mixing effect of organic cations on the structural, electronic and optical properties of $\mathrm{FA}_{x} \mathrm{MA}_{1-\mathrm{x}} \mathrm{PbI}_{3}$ perovskites. Phys. Chem. Chem. Phys. 2018, 20, 941-950. [CrossRef]

83. Chang, S.H.; Lin, K.-F.; Chiang, C.-H.; Chen, S.-H.; Wu, C.-G. Plasmonic structure enhanced exciton generation at the interface between the perovskite absorber and copper nanoparticles. Sci. World J. 2014, 2014, 128414. [CrossRef] [PubMed]

84. Xie, Z.; Sun, S.; Yan, Y.; Zhang, L.; Hou, R.; Tian, F.; Qin, G.G. Refractive index and extinction coefficient of $\mathrm{NH}_{2} \mathrm{CH}_{\mathrm{H}} \mathrm{NH}_{2} \mathrm{PbI}_{3}$ perovskite photovoltaic material. J. Phys. Condens. Matter. 2017, 29, 245702. [CrossRef] [PubMed]

85. Jung, M.-L. Formation of cubic perovskite alloy containing the ammonium cation of 2D perovskite for high performance solar cells with improved stability. RSC Asv. 2021, 11, 32590. [CrossRef]

86. Yang, Z.; Surrente, A.; Galkowski, K.; Bruyant, N.; Maude, D.K.; Haghighirad, A.A.; Snaith, H.J.; Plochocka, P.; Nicholas, R.J. Unraveling the exciton binding energy and the dielectric constant in single-crystal methylammonium lead triiodide perovskite. $J$. Phys. Chem. Lett. 2017, 8, 1851-1855. [CrossRef]

87. Liu, Y.; Wang, J.; Zhang, L.; Liu, W.; Wu, C.; Liu, C.; Wu, Z.; Xiao, L.; Chen, Z.; Wang, S. Exciton and bi-exciton mechanisms in amplified spontaneous emission from CsPbBr3 perovskite thin films. Opt. Express 2019, 27, 29124-29132. [CrossRef]

88. Chen, S.; Nurmikko, A. Exciton gain and laser emission from mixed cation halide perovskite thin films. Opt. Express 2018, 5, 1141-1149.

89. Chen, L.-C.; Lin, Y.-S.; Tseng, Z.-L.; Wu, C.; Kao, F.-S.; Chen, S.-H. Overcoming the intrinsic difference between hydrophilic $\mathrm{CH}_{3} \mathrm{NH}_{3} \mathrm{PbI}_{3}$ and hydrophobic $\mathrm{C}_{60}$ thin films to improve the photovoltaic performance. Nanomaterials 2017, 7, 166. [CrossRef]

90. Zhang, Y.; Kim, S.-G.; Lee, D.; Shin, H.; Park, N.-G. Bifacial stamping for high efficiency perovskite solar cells. Energy Environ. Sci. 2019, 12, 308-321. [CrossRef]

91. Solanki, A.; Yadav, P.; Turren-Cruz, S.-H.; Lim, S.S.; Salliba, M.; Sum, T.C. Cation influence on carrier dynamics in perovskite solar cells. Nano Energy 2019, 58, 604-611. [CrossRef]

92. Motta, C.; El-Mellouhi, F.; Sanvito, S. Charge carrier mobility in hybrid halide perovskites. Sci. Rep. 2015, 5, 12746. [CrossRef]

93. Gelvez-Rueda, M.C.; Renaud, N.; Grozema, F.C. Temperature dependent charge carrier dynamics in formamidinium lead iodide perovskite. J. Phys. Chem. C 2017, 121, 23392-23397. [CrossRef]

94. Chen, Y.; Yi, H.T.; Wu, X.; Haroldson, R.; Gartstein, Y.N.; Rodionov, Y.I.; Tikhonov, K.S.; Zakhidov, A.; Zhu, X.-Y.; Podzorov, Y. Extended carrier lifetimes and diffusion in hybrid perovskites revealed by Hall effect and photoconductivity measurments. Nat. Commun. 2016, 7, 12253. [CrossRef]

95. Hwang, H.; Park, S.; Heo, J.H.; Kim, W.; Ahn, H.; Kim, T.-S.; Im, S.H.; Son, H.J. Enhancing performance and stability of perovskite solar cells using hole transport layer of small molecule and conjugated polymer blend. J. Power Sources 2019, 418, 167-175. [CrossRef]

96. Liu, Y.; Hu, Y.; Zhang, X.; Zeng, P.; Li, F.; Wang, B.; Yang, Q.; Liu, M. Inhibited aggregation of lithium salt in spiro-OMeTAD toward highly efficient perovskite solar cells. Nano Energy 2020, 70, 104483. [CrossRef]

97. Desoky, M.M.; Bonomo, M.; Buscaino, R.; Fin, A.; Vicardi, G.; Barolo, C.; Quagliotto, P. Dopant-free all-organic small-molcule HTMs for perovskite solar cells: Concepts and structure-property relationships. Energies 2021, 14, 2279. [CrossRef]

98. Fang, Y.; Bi, C.; Wang, D.; Huang, J. The functions of fullerenes in hybrid perovskite solar cells. ACS Energy Lett. 2017, 2, 782-794. [CrossRef]

99. Chiu, K.Y.; Chang, S.H.; Huang, W.-C.; Cheng, H.-M.; Shaw, H.; Yeh, S.-C.; Chen, C.-T.; Su, Y.O.; Chen, S.-H.; Wu, C.-G. Functional graded fullerene derivatives for improving the fill factor and device stability of inverted-type perovskite solar cells. Nanotechnology 2018, 29, 305701. [CrossRef] [PubMed]

100. Wu, F.; Gao, W.; Yu, H.; Zhu, L.; Li, L.; Yang, C. Efficient small-molecule non-fullerene electron transporting materials for high-performance inverted perovskite solar cells. J. Mater. Chem. A 2018, 6, 4443-4448. [CrossRef]

101. Wang, P.; Shao, Z.; Ulfa, M.; Pauporte, T. Insights into the hole blocking layer effect on the perovskite solar cell performance and impedance response. J. Phys. Chem. C 2017, 121, 9131-9141. [CrossRef]

102. Lee, K.-M.; Chen, K.-S.; Wu, J.-R.; Lin, Y.-D.; Yu, S.-M.; Chang, S.H. Highly efficient and stable semi-transparent perovskite solar modules with a trilayer anode electrode. Nanoscale 2018, 10, 17699-17704. [CrossRef] [PubMed]

103. Tavakoli, M.M.; Tavakoli, R.; Prochowicz, D.; Yadav, P.; Saliba, M. Surface modification of a hole transporting layer for an efficient perovskite solar cell with an enhanced fill factor and stability. Mol. Syst. Des. Eng. 2018, 3, 717-722. [CrossRef]

104. Chen, C.; Zhang, S.; Wu, S.; Zhang, W.; Zhu, X.Z.; Zhang, Y.; Che, W. Effect of BCP buffer layer on eliminating charge accumulation for high performance of inverted perovskite solar cells. RSC Adv. 2017, 7, 35819. [CrossRef]

105. Wu, H.-T.; Cheng, Y.-T.; Leu, C.-C.; Wu, S.-H.; Shih, C.-F. Improving two-step prepared CH3NH3PbI3 perovskite solar cells by co-doping potassium halide and water in PbI2 layer. Nanomaterials 2019, 9, 666. [CrossRef]

106. Jafari, F.; Patil, B.R.; Motaram, F.; Cauduro, A.L.F.; Rubahn, H.-G.; Behjat, A.; Madsen, M. Inverted organic solar cells with non-clustering bathocuproine (BCP) cathode interlayers obtained by fullerene doping. Sci. Rep. 2019, 9, 10422. [CrossRef] [PubMed] 
107. Kong, J.; Wang, H.; Rohr, J.A.; Fishman, Z.S.; Zhu, Y.; Li, M.; Cotlet, M.; Kim, G.; Karpovich, C.; Antonio, F.; et al. Perovskite solar cells with enhanced fill factors using polymer-capped solvent annealing. ACS Appl. Energy Mater. 2020, 3, 7231-7238. [CrossRef]

108. Chiang, C.-H.; Wu, C.-G. A method for the preparation of highly oriented $\mathrm{MAPbI}_{3}$ crystallities for high-efficiency perovskite solar cells to achieve an 86\% fill factor. ACS Nano 2018, 12, 10355-10364. [CrossRef]

109. Frost, J.M.; Butler, K.T.; Brivio, F.; Hendon, C.H.; van Schilfgaared, M.; Walsh, A. Atomistic origins of high-performance in hybrid halide perovskite solar cells. Nano Leet. 2014, 14, 2584-2590. [CrossRef]

110. Hsu, H.-C.; Huang, B.-C.; Chin, S.-C.; Hsing, C.-R.; Nguyen, D.-L.; Schnedler, M.; Dunin-Borkowski, R.S.R.E.; Wei, C.-M.; Chen, C.-W.; Ebert, P.; et al. Photodriven dipole reordering: Key to carrier separation in metalorganic halide perovskites. ACS Nano 2019, 13, 4402-4409. [CrossRef]

111. Chen, C.-J.; Chandel, A.; Thakur, D.; Wu, J.-R.; Chiang, S.-E.; Zeng, G.-S.; Shen, J.-L.; Chen, S.-H.; Chang, S.H. Ag modified bathocuproine: $\mathrm{ZnO}$ nanoparticles electron buffer layer based bifacial inverted-type perovskite solar cells. Org. Electron. 2021, 92, 106110. [CrossRef]

112. Kim, D.H.; Park, J.; Li, Z.; Yang, M.; Park, J.-S.; Park, I.J.; Kim, J.Y.; Berry, J.J.; Rumbles, G.; Zhu, K. 300\% enhancement of carrier mobility in uniaxial-oriented perovskite films formed by topotactic-oriented attachment. Adv. Mater. 2017, 29, 1606831. [CrossRef] [PubMed]

113. Han, X.; Wang, X.; Feng, J.; Huang, H.; Zhu, Z.; Yu, T.; Li, Z.; Zou, Z. Carrier mobility enhancement in (121)-oriented CsPbBr 3 perovskite films induced by the microstructure tailoring of $\mathrm{PbBr}_{2}$ precursor films. ACS Appl. Electron. Mater. 2021, 3, 373-384. [CrossRef]

114. Meng, G.; Hao, C.; Ji, M.; Shi, Y. Theoretical insights into the carrier mobility anisotropy of organic-inorganic perovskite $\mathrm{ABI}_{3}(\mathrm{~A}$ $=\mathrm{CH}_{3} \mathrm{NH}_{3}$ and $\mathrm{HC}\left(\mathrm{NH}_{2}\right)_{2} ; \mathrm{B}=\mathrm{Pb}$ and $\left.\mathrm{Sn}\right) . J$. Phys. Chem. C 2021, 125, 22446-22456. [CrossRef]

115. Liao, Q.; Wang, Y.; Yao, X.; Su, M.; Li, B.; Sun, H.; Huang, J.; Guo, X. A dual-functional conjugated polymer as an efficient hole-transporting layer for high-performance inverted perovskite solar cells. ACS Appl. Mater. Interfaces 2021, 13, 16744-16753. [CrossRef]

116. Lin, Y.-J.; Yang, F.-M.; Huang, C.-Y.; Chou, W.-Y.; Chang, J.; Lien, Y.-C. Increasing the work function of poly((3,4ethylenedioxythiophene) doped with poly(4-styrenesulfonate) by ultraviolet irradiation. Appl. Phys. Lett. 2007, 91, 092127. [CrossRef]

117. Sze, P.-W.; Lee, K.-W.; Huang, P.-C.; Chou, D.-W.; Kao, B.-S.; Huang, C.-J. The investigation of high quality PEDOT:PSS film by multilayer-processing and acid treatment. Energies 2017, 10, 716. [CrossRef]

118. Lee, H.; Kim, Y.; Cho, H.; Lee, J.-G.; Kim, J.H. Improvement of PEDOT:PSS linearity via controlled addition process. RSC Adv. 2019, 9, 17318-17324. [CrossRef]

119. Yu, J.C.; Hong, J.A.; Jung, E.D.; Kim, D.B.; Baek, S.-M.; Lee, S.; Cho, S.; Park, S.S.; Choi, K.J.; Song, M.H. Highly efficient and stable inverted perovskite solar cell emplogying PEDOT:GO composite layer as a hole transport layer. Sci. Rep. 2018, 8, 1070. [CrossRef]

120. Luo, H.; Lin, X.; Hou, X.; Pan, L.; Huang, S.; Chen, X. Efficient and air-stable planar perovskite solar cells formed on graphemeoxide-modified PEDOT:OSS hole transport layer. Nano-Micro Lett. 2017, 9, 39.

121. Niu, J.; Yang, D.; Ren, X.; Yang, Z.; Liu, Y.; Zhu, X.; Zhao, W.; Liu, S. Grphene-oxide doped PEDOT:PSS as a superior hole transport material for high-efficiency perovskite solar cell. Org. Electron. 2017, 48, 165-171. [CrossRef]

122. Wang, Y.; Hu, Y.; Han, D.; Yuan, Q.; Cao, T.; Chen, N.; Zhou, D.; Cong, H.; Feng, L. Ammonia-treated grapheme oxide and PEDOT:PSS as hole transport layer for high-performance perovskite solar cells with enhanced stability. Org. Electron. 2019, 70, 63-70. [CrossRef]

123. Kornilov, D.Y.; Gubin, S.P. Graphene oxide: Structure, properties, synthesis, and reduction (a review). Russ. J. Inorg. Chem. 2020, 65, 1965-1976. [CrossRef]

124. Yin, X.; Que, M.; Xing, Y.; Que, W. High efficiency hysteresis-less inverted planar heterojunction perovskite solar cells with a solution-derived NiOx hole contact layer. J. Mater. Chem. A 2015, 3, 24495-24503. [CrossRef]

125. Duan, J.; Zhang, Y.; Yu, D.; Wang, F.; Dai, J. High performance inverted planar $\mathrm{MAPbI}_{3}$ perovskite solar cells with a simple annealing process. ChemNanoMat 2019, 5, 715-722. [CrossRef]

126. Dharmadasa, I.M.; Rahaq, Y.; Alam, A.E. Perovskite solar cells: Short lifetime and hysteresis behavior of current-voltage characteristics. J. Mater. Sci. Mater. Electron. 2019, 30, 12851-12859. [CrossRef]

127. Jiang, Y.; Li, C.; Liu, H.; Qin, R.; Ma, H. Ploy(3,4-ethylenedioxythiophene):polu(styrenesulfonate) (PEDOT:PSS)-molybdenum oxide composite films as hole conductors for efficient planar perovskite solar cells. J. Mater. Chem. A 2016, 4, 9958-9966. [CrossRef]

128. Wang, Z.-K.; Li, M.; Yuan, D.-X.; Shi, X.-B.; Ma, H.; Liao, L.-S. Improved hole interfacial layer for planar perovskite solar cells with efficiency exceeding 15\%. ACS Appl. Mater. Interfaces 2015, 7, 9645-9651. [CrossRef]

129. Pakr, I.J.; Park, M.A.; Kim, D.H.; Park, G.D.; Kim, B.J.; Son, H.J.; Ko, M.J.; Lee, D.-K.; Park, T.; Shin, H.; et al. New hybrid hole extraction layer of perovskite solar cells with a planar p-i-n geometry. J. Phys. Chem. C 2015, 119, 27285-27290.

130. Intaniwer, A.; Mills, C.A.; Shkunov, M.; Thiem, H.; Keddie, J.L.; Sellin, P.J. Characterization of thick film poly(triarylamine) semiconductor diodes for direct x-ray detection. J. Appl. Phys. 2009, 106, 064513. [CrossRef]

131. Neumann, K.; Thelakkat, M. Perovskite solar cells involving poly(tetraphenylbenzidine)s: Investigation of hole carrier mobility, doping effects and photovoltaic properties. RSC Adv. 2014, 4, 43550-43559. [CrossRef]

132. Rombach, F.M.; Haque, S.A.; Macdonald, T.J. Lessons learned from spiro-OMeTAD and PTAA is perovskite solar cells. Energy Environ. Sci. 2021, 14, 5161. [CrossRef] 
133. Chen, B.; Yu, Z.J.; Manzoor, S.; Wang, S.; Weigand, W.; Yu, Z.; Yang, G.; Ni, Z.; Dai, X.; Holman, Z.C.; et al. Blade-coated perovskite on textured silicon for 26\%-efficient monolithic perovskite/silicon tandem solar cells. Joule 2020, 4, 850-864. [CrossRef]

134. Li, Y.; Liang, C.; Wang, G.; Li, J.; Chen, S.; Yang, S.; Xing, G.; Pan, H. Two-step solvent post-treatment on PTAA for highly efficient and stable inverted perovskite solar cells. Photonics Res. 2020, 8, A39-A49. [CrossRef]

135. Wang, C.; Su, Z.; Chen, L.; Zhang, H.; Hui, W.; Liang, D.; Zheng, G.; Zhang, L.; Tang, Z.; Wen, W.; et al. MoO 3 doped PTAA for high-performance inverted perovskite solar cells. Appl. Surf. Sci. 2022, 571, 151301. [CrossRef]

136. Gil, B.; Kim, J.; Yun, A.J.; Park, K.; Cho, J.; Park, M.; Park, B. $\mathrm{CuCrO}_{2}$ nanoparticles incorporated into PTAA as a hole transport layer for $85^{\circ} \mathrm{C}$ and light stabilities in perovskite solar cells. Nanomaterials 2020, 10, 1669. [CrossRef] [PubMed]

137. Li, X.; Wang, Y.-C.; Zhu, L.; Zhang, W.; Wang, H.-Q.; Fang, J. Improving efficiency and reproducibility of perovskite solar cells through aggregation control in polyelectrolytes hole transport layer. ACS Appl. Mater. Interfaces 2017, 9, 31357-31361. [CrossRef] [PubMed]

138. Li, J.; Zhao, M.; Zhao, C.; Jian, H.; Wang, N.; Yao, L.; Huang, C.; Zhao, Y.; Jiu, T. Graphidyne-doped P3CT-L as an efficient hole-transport layer for $\mathrm{MAPbI}_{3}$ perovskite solar cells. ACS Appl. Mater. Interfaces 2019, 11, 2626-2631. [CrossRef] [PubMed]

139. Li, C.-Y.; Chandel, A.; Wu, J.-R.; Thakur, D.; Chiang, S.-E.; Cheng, K.-J.; Chen, S.-H.; Shen, J.-L.; Chang, S.H. Highly efficient and stable P3TC-Na based MAPbI3 solar cells with a Sn-rich ITO anode. Sol. Energy Mater. Sol. Cells 2021, 231, 111305. [CrossRef]

140. Bi, C.; Wang, Q.; Shao, Y.; Yuan, Y.; Xiao, Z.; Huang, J. Non-wetting surface-driven high-aspect-ratio crystalline grain growth for efficient hybrid perovskite solar cells. Nat. Commun. 2015, 6, 7747. [CrossRef]

141. Yao, Y.; Hsu, W.-L.; Dagenais, M. High-efficiency perovskite solar cell based on sequential doping of PTAA. IEEE J. Photovolt. 2019, 9, 1025-1030. [CrossRef]

142. Bagheri, Z.; Matteocci, F.; Lamanna, E.; Girolamo, D.D.; Marrani, A.G.; Zanoni, R.; Carlo, A.D.; Moshaii, A. Light-induced improvement of dopant-free PTAA on performance of inverted perovskite solar cells. Sol. Energy Mater. Sol. Cells 2020, 215, 110606. [CrossRef]

143. Zhao, D.; Sexton, M.; Park, H.-Y.; Baure, G.; Nino, J.C.; So, F. High-efficiency solution-processed planar perovskite solar cells with a polymer hole transport layer. Adv. Energy Mater. 2015, 5, 1401855. [CrossRef]

144. Safari, Z.; Zarandi, M.B.; Giuri, A.; Bisconti, F.; Carallo, S.; Listorti, A.; Corcione, C.E.; Nateghi, M.R.; Rizzo, A.; Colella, S. Optimizing the interface between hole transporting material and nanocomposite for highly efficient perovskite solar cells. Nanomaterials 2019, 9, 1627. [CrossRef]

145. Coskun, H.; Iskigor, F.H.; Chen, Z.; Imran, M.; Li, B.; Xu, Q.; Quyang, J. Thermally evaporated two-dimensional SnS as an efficient and stable electron collection interlayer for inverted planar perovskite solar cells. J. Mater. Chem. A 2019, 7, 4759-4765. [CrossRef]

146. Chandel, A.; Ke, Q.B.; Thakur, D.; Chiang, S.-E.; Wu, J.-R.; Cai, K.-B.; Yuan, C.-T.; Chang, S.H. Regioregularity effects of p-type P3CT-Na polymers on inverted perovskite photovoltaic cells. Org. Electron. 2022, 102, 106449. [CrossRef]

147. Tzoganakis, N.; Feng, B.; Loizos, M.; Krassas, M.; Tsikritzis, D.; Zhuang, X.; Kymakis, E. Ultrathin PTAA interlayer in conjunction with azulene derivatives for the fabrication of inverted perovskite solar cells. J. Mater. Chem. C 2021, 9, 14709-14719. [CrossRef]

148. Wu, S.; Zhang, J.; Li, Z.; Liu, D.; Qin, M.; Cheung, S.H.; Lu, X.; Lei, D.; So, S.K.; Zhu, Z.; et al. Modulation of defects and interfaces through alkylammonium interlayer for efficient inverted perovskite solar cells. Joule 2020, 1248-1262. [CrossRef]

149. Zhou, Q.; Qiu, J.; Wang, Y.; Yu, M.; Liu, J.; Zhang, X. Multifunctional chemical bridge and defect passivation for highly efficient inverted perovskite solar cells. ACS Energy Lett. 2021, 6, 1596-1606. [CrossRef]

150. Hsieh, H.-C.; Hsiow, C.-Y.; Lin, K.-F.; Shih, Y.-C.; Wang, L.; Renaud, C.; Nguyen, T.-P. Analysis of defects and traps in N-I-P layered-structure of perovskite solar cells by charge-based deep level transient spectroscopy (Q-DLTS). J. Phys. Chem. C 2018, 122, 17601-17611. [CrossRef]

151. Cho, S.H.; Byeon, J.; Jeong, K.; Hwang, J.; Lee, H.; Jang, J.; Lee, J.; Kim, T.; Kim, K.; Choi, M.; et al. Investigation of defect-tolerant perovskite solar cells with long-term stability via controlling the self-doping effect. Adv. Energy Mater. 2021, 11, 2100555. [CrossRef]

152. Kassou, S.; Wu, J.-R.; Thakur, D.; Chandel, A.; Chiang, S.-E.; Cheng, K.-R.; Chen, S.-H.; Shen, J.-L.; Chang, S.H. Efficiency improvement of $\mathrm{P} 3 \mathrm{TC}-\mathrm{Na}$ based $\mathrm{MAPbI}_{3}$ solar cells with a simple wetting process. Nanotechnology 2021, 32, 345402. [CrossRef] [PubMed]

153. Liu, C.; Li, W.; Li, H.; Zhang, C.; Fan, J.; Mai, Y. $\mathrm{C}_{60}$ additive-assisted crystallization in $\mathrm{CH}_{3} \mathrm{NH}_{3} \mathrm{~Pb}_{0.75} \mathrm{Sn}_{0.25} \mathrm{I}_{3}$ perovskite solar cells with high stability and efficiency. Nanoscale 2017, 9, 13967-13975. [CrossRef] [PubMed]

154. Jiang, X.; Wang, F.; Wei, Q.; Li, H.; Shang, Y.; Zhou, W.; Wang, C.; Cheng, P.; Chen, Q.; Chen, L.; et al. Ultra-high open-circuit voltage of tin perovskite solar cells via an electron transporting layer design. Nat. Commun. 2020, 11, 1245. [CrossRef]

155. Said, A.A.; Xie, J.; Zhang, Q. Recent progress in organic electron transport materials in inverted perovskite solar cells. Small 2019, 15, 1900854. [CrossRef]

156. Yang, Q.; Liu, X.; Yu, S.; Feng, Z.; Liang, L.; Qin, W.; Wang, Y.; Hu, X.; Chen, S.; Feng, Z.; et al. Hydroxylated non-fullerene acceptor for highly efficient inverted perovskite solar cells. Energy Environ. Sci. 2021, 14, 6536-6545. [CrossRef]

157. Xiao, Z.; Dong, Q.; Bi, C.; Shao, Y.; Yuan, Y.; Huang, J. Solvent annealing of perovskite-induced crystal growth for photovoltaicdevice efficiency enhancement. Adv. Mater. 2014, 26, 6503-6509. [CrossRef]

158. Gueye, M.N.; Carella, A.; Massonnet, N.; Yvenou, E.; Brenet, S.; Faure-Vincent, J.; Pouget, S.; Rieutord, F.; Okuno, H.; Benayad, A.; et al. Structure and dopant engineering in PEDOT thin films: Practical tools for a dramatic conductivity enhancement. Chem. Mater. 2016, 28, 3462-3468. [CrossRef] 
159. Thakur, D.; Chiang, S.-E.; Yang, M.-H.; Wang, J.-S.; Chang, S.H. Self-stability of un-encapsulated polycrystalline MAPbI3 solar cells via the formation of chemical bonds between $\mathrm{C}_{60}$ molecules and MA cations. Sol. Energy Mater. Sol. Cells 2022, $235,111454$. [CrossRef]

160. Lee, I.; Rolston, N.; Brunner, P.-L.; Dauskardt, R.H. Hole-transport layer molecular weight and doping effects on perovskite solar cell efficiency and mechanical behavior. ACS Appl. Mater. Interfaces 2019, 11, 23757-23764. [CrossRef]

161. Nia, N.Y.; Mendez, M.; Paci, B.; Generosi, A.; Carlo, A.D.; Palomares, E. Analysis of the efficiency losses in hybrid perovskite/PTAA solar cells with different molecular weights: Morphology versus kinetics. ACS Appl. Energy Mater. 2020, 3 , 6853-6859.

162. Abdelghafour, M.M.; Orban, A.; Deak, A.; Lamch, L.; Frank, E.; Nagy, R.; Adam, A.; Sipos, P.; Farkas, E.; Bari, F.; et al. The effect of molecular weight on the solubility properties of biocompatible poly(ethylene succinate) polyester. Polymers 2021, 13, 2725. [CrossRef] [PubMed] 